\title{
Unified concepts for understanding and modelling turnover of dissolved organic matter from freshwaters to the ocean: the UniDOM model
}

\author{
T. R. Anderson $\cdot$ E. C. Rowe $\cdot$ L. Polimene $\cdot$ E. Tipping $\cdot$ C. D. Evans $\cdot$ \\ C. D. G. Barry • D. A. Hansell • K. Kaiser · V. Kitidis • D. J. Lapworth • \\ D. J. Mayor - D. T. Monteith - A. E. Pickard - R. J. Sanders - B. M. Spears • \\ R. Torres $\cdot$ A. M. Tye $\cdot$ A. J. Wade $\cdot$ H. Waska
}

Received: 18 March 2019/Accepted: 12 November 2019/Published online: 25 November 2019

(C) The Author(s) 2019

\begin{abstract}
The transport of dissolved organic matter (DOM) across the land-ocean-aquatic-continuum (LOAC), from freshwater to the ocean, is an important yet poorly understood component of the global carbon budget. Exploring and quantifying this flux is a significant challenge given the complexities of DOM cycling across these contrasting environments. We developed a new model, UniDOM, that unifies concepts, state variables and parameterisations of DOM turnover across the LOAC. Terrigenous DOM is
\end{abstract}

Communicated by Marc G Kramer.

Electronic supplementary material The online version of this article (https://doi.org/10.1007/s10533-019-00621-1) contains supplementary material, which is available to authorized users.

T. R. Anderson ( $₫)$ · D. J. Mayor · R. J. Sanders

National Oceanography Centre, Southampton SO14 3ZH, UK

e-mail: tra@noc.ac.uk

E. C. Rowe - C. D. Evans - C. D. G. Barry

Centre for Ecology and Hydrology, Bangor LL57 2UW, UK

L. Polimene $\cdot$ V. Kitidis $\cdot$ R. Torres

Plymouth Marine Laboratory, Plymouth PL1 3DH, UK

E. Tipping · D. T. Monteith

Centre for Ecology and Hydrology, Lancaster LA1 4AP, UK divided into two pools, $\mathrm{T}_{1}$ (strongly-UV-absorbing) and $\mathrm{T}_{2}$ (non- or weakly-UV-absorbing), that exhibit contrasting responses to microbial consumption, photooxidation and flocculation. Data are presented to show that these pools are amenable to routine measurement based on specific UV absorbance (SUVA). In addition, an autochtonous DOM pool is defined to account for aquatic DOM production. A novel aspect of UniDOM is that rates of photooxidation and microbial turnover are parameterised as an inverse function of DOM age. Model results, which indicate that $\sim 5 \%$ of the DOM originating in streams may penetrate into the open ocean, are sensitive to this parameterisation, as well as rates assigned to turnover of freshly-produced DOM. The predicted contribution of flocculation to DOM turnover is remarkably low,

D. A. Hansell

University of Miami, Miami, FL 33149, USA

K. Kaiser

Martin Luther University Halle-Wittenberg, 06120 Halle, Germany

D. J. Lapworth

British Geological Survey, Wallingford OX10 8BB, UK

A. E. Pickard - B. M. Spears

Centre for Ecology and Hydrology,

Edinburgh EH26 0QB, UK

A. M. Tye

British Geological Survey, Keyworth NG12 5GG, UK 
although a mechanistic representation of this process in UniDOM was considered unachievable because of the complexities involved. Our work highlights the need for ongoing research into the mechanistic understanding and rates of photooxidation, microbial consumption and flocculation of DOM across the different environments of the LOAC, along with the development of models based on unified concepts and parameterisations.

Keywords Terrigenous dissolved organic matter . Land ocean aquatic continuum (LOAC) .

Biogeochemical model · Biogeochemistry · Photooxidation

\section{Introduction}

Terrigenous dissolved organic matter (DOM) plays a major role in the storage and cycling of carbon (C) at regional and global scales (Tranvik et al. 2009). The flux of $\mathrm{C}$ from soils to freshwater systems may be as high as 1.9-5.1 Pg C year ${ }^{-1}$ (Cole et al. 2007; Drake et al. 2018), of which a significant, although as yet not well constrained, proportion is as DOM (Raymond and Spencer 2015; Massicotte et al. 2017; Drake et al. 2018). Calculations of the global carbon budget (e.g., Ciais et al. 2013), including those derived from earth system models (ESMs), do not, however, explicitly represent the processes involved in the transfer of dissolved organic carbon (DOC) throughout the landocean-aquatic-continuum (LOAC), which spans freshwater, estuaries and the ocean. One reason is that sequestration of terrigenous DOC in the ocean was considered negligible for many years: isotopic signatures and absence of traditional terrestrial biomarkers (e.g., lignin) suggested that the large pool of oceanic DOM ( 700 Pg C: Hansell and Carlson 1998) is produced mostly in situ. Recent results from molecular fingerprinting techniques have, however, demonstrated the presence of otherwise undetectable (in the pico-to nanomolar concentration range) terrestrially-

A. J. Wade

University of Reading, Reading RG6 6AH, UK

H. Waska

University of Oldenburg, 26129 Oldenburg, Germany derived compounds far into the open ocean (Medeiros et al. 2016, Riedel et al. 2016). A second reason why DOC processes have not been afforded an explicit representation in calculations of the global $\mathrm{C}$ budget is the sheer difficulty of developing mechanistic models of DOC turnover that span the entire LOAC, given the complexity of the system and associated uncertainties (Le Quéré et al. 2015). The requirement is for unified concepts of DOM turnover, based on mechanistic understanding of the underlying processes, in order to develop a unified model that has a single set of state variables and parameterisations that are applicable from freshwaters to the ocean. There are in existence models of DOC for individual parts of the LOAC (e.g., Futter et al. 2007; Bauer et al. 2013), but the different research communities have adopted differing concepts and nomenclature.

Here, we develop a new cross-system model, UniDOM (Unified model of Dissolved Organic Matter), that unifies process representations (i.e., provides a common set of concepts, state variables and parameterisations) across freshwater, estuarine and ocean systems. The development of UniDOM has two main aims. Our first and primary objective is to identify knowledge gaps in the turnover of terrigenous DOC across the LOAC, stimulating discussion and the evolution of new ideas, including associated modelling approaches. "By forcing one to produce formulas to define each process and put numbers to the coefficients, [a simulation of a natural ecosystem] reveals the lacunae in one's knowledge...the main aim is to determine where the model breaks down and use it to suggest further field or experimental work" (Steele 1974). Our second aim is to present UniDOM as a fully functional mathematical model that represents the bulk DOC pool, and to use the model to provide a preliminary assessment of the extent to which terrigenous DOC traverses the LOAC and penetrates into the ocean. For this purpose, UniDOM is implemented in a simple physical framework with residence times for freshwater, estuaries and the ocean that are representative of United Kingdom waters.

\section{UniDOM: conceptual basis}

The main focus of UniDOM is DOC turnover across the entire LOAC. The requirement is to develop a model structure and associated parameterisations that 
capture the decline in concentration, along with associated changes in composition, as terrigenous DOC is acted on by different turnover processes, namely biological consumption, photooxidation and flocculation. The selection of state variables is of paramount importance in this regard and, after much debate (including two workshops), we chose to represent terrigenous DOC as two fractions, $\mathrm{T}_{1}$, and $\mathrm{T}_{2}$, with a third state variable for an autochthonous aquatic fraction, A (Fig. 1). The thinking behind this structure is described in this section, noting that a key consideration is that the different DOC fractions and associated rate processes should be amenable to straightforward and high-throughput measurement in the field and laboratory. A full mathematical description of UniDOM is presented later.

Terrigenous DOM typically contains a large fraction of aromatic compounds, most notably lignin, but also a variety of secondary metabolites (Verhoeven and Liefveld 1997). These compounds are mostly of structural origin and thereby resistant to biological decomposition. Lignin, which is produced by terrestrial and aquatic vascular plants (Webster and Benfield 1986; Kirk and Farrell 1987; Kalbitz et al. 2003), and

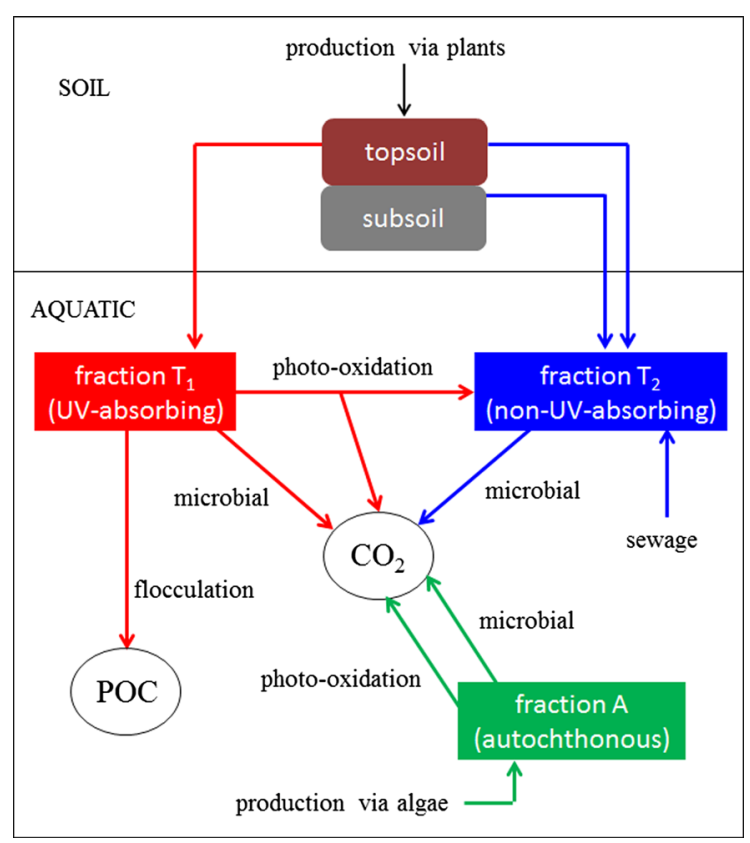

Fig. 1 Flow diagram of the UniDOM model showing production and turnover of DOC within the LOAC (rivers and lakes, estuaries and ocean): terrigenous fractions $T_{1}$ and $T_{2}$, and autochthonous (A) associated structural polysaccharides such as cellulose and hemicellulose (Webster and Benfield 1986), are good examples, although turnover rates of these compounds can nevertheless be significant (Ward et al. 2017). These chemical structures also contribute to the coloured or chromophoric DOM fraction (CDOM) and render the compounds prone to photooxidation by ultraviolet (UV) radiation (Cory et al. 2015; Koehler et al. 2016; Berggren et al. 2018). For example, Opsahl and Benner (1998) noted that $75 \%$ of lignin was photo-oxidised over 28 days in the Mississippi River, while Spencer et al. (2009) noted a 95\% reduction when Congo River water was irradiated for 57 days.

Aromatic compounds are most readily precipitated by metal ions given their susceptibility to sorption and co-precipitation with reactive minerals (Vilge-Ritter et al. 1999; Riedel et al. 2012). Flocculation may be highest in estuaries for several reasons. High concentrations of particulate matter in estuaries promotes flocculation, especially in the turbidity maximum (Vinh et al. 2018). High ionic strength also facilitates flocculation by neutralising negative surface charges on DOM. Metal salts enhance flocculation, e.g., iron is precipitated as waters of terrestrial origin enter estuaries (Charette and Sholkovitz 2002). Flocculation requires molecules to collide and so, along with deflocculation, depends on hydrodynamic forcing, notably Brownian motion and fluid shear, i.e., turbulence (Kepkay 1994; Wang et al. 2013). The greater turbulence within estuaries relative to lakes and the ocean therefore further contributes to the potential for estuarine environments as hotspots for DOM flocculation (Geyer et al. 2008).

Based on the above, we define $T_{1}$ as the fraction that includes compounds such as lignin and other structural entities that are prone to photooxidation and flocculation, but relatively resistant to microbial decomposition. Conversely, we classify $\mathrm{T}_{2}$ compounds as those that are not readily photooxidised or flocculated, but which are more susceptible to microbial processing. The $T_{1}: T_{2}$ partition is further justified in context of carbon fluxes across the LOAC by the observation that it is aromatic fraction that dominates the signal of terrigenous DOM in the open ocean (Meyers-Schulte and Hedges 1986; Hedges et al. 1997; Opsahl and Benner 1997). It is tempting to use aromaticity as the specific criterion for defining the division of terrigenous DOM between $\mathrm{T}_{1}$ and $\mathrm{T}_{2}$, but we choose not to do 
so because photooxidation is not exclusively restricted to aromatic compounds. Carboxylic acids are also prone to photooxidation (Xie et al. 2004; Gonsior et al. 2013), as are some proteins (Janssen and McNeill 2014). Instead, we operationally define $T_{1}$ as terrigenous DOM that strongly absorbs UV radiation, whereas $\mathrm{T}_{2}$ represents compounds that are only weakly or not absorbing for UV, such as many carbohydrates and proteins.

Autochthonous DOM is produced in situ throughout the LOAC via a range of processes including phytoplankton exudation, zooplankton grazing and detritus turnover (e.g., Anderson and Williams 1998). Algae typically do not contain lignin although ligninlike compounds, e.g., sporopollenin, are sometimes present (Gunnison and Alexander 1975). Recalcitrant compounds are nevertheless present in autochthonous DOM, such as detritus in marine systems that contains structural polysaccharides (Mann 1988) that require solubilisation by exoenzymes in order to be utilised by bacteria (Chróst 1990). CDOM is thought to be a byproduct of microbial processing and metabolism (Rochelle-Newall and Fisher 2002; Nelson et al. 2004; Romera-Castillo et al. 2011; Kinsey et al. 2018), is present within autochthonous DOM and is ubiquitous in both freshwater systems (Kutser et al. 2005) and the world ocean (Nelson and Siegel 2013). A significant fraction of CDOM may be loosely classed as humic material (Nelson and Siegel 2013; Kellerman et al. 2018), although the aromatic content is usually lower than that of soil organic matter (McKnight et al. 2001). Autochthonous DOM also includes colloidal material such as gels and transparent exopolymer particles (TEP) that aggregates to form flocs of marine snow (Santschi 2018).

The inclusion of autochthonous DOC in UniDOM is required in order to meet our objective to provide a fully functional model that represents the bulk DOC pool. Noting that the main focus of our study is terrigenous DOC $\left(\mathrm{T}_{1}\right.$ and $\mathrm{T}_{2}$ ), we adopt a simple approach whereby the autochthonous fraction is represented as a single state variable, A. As with DOM in general, autochthonous DOM comprises a spectrum of compounds of varying lability. A fraction is present as simple sugars that are rapidly consumed by bacteria on timescales of hours to days (Søndergaard and Middelboe 1995) and, as such, are unlikely to contribute significantly to lateral fluxes given that the transit time for DOM traversing the LOAC is usually at least a few days. Instead, and in common with other modelling studies of marine DOM (e.g., Schmittner et al. 2005; Salihoglu et al. 2008), our use of a single state variable for A represents semi-labile compounds that turn over on timescales of weeks to months. Compounds may be rendered semi-labile for a number of reasons including the requirement for exoenzyme hydrolysis, low concentrations of individual biomolecules, the presence of competing substrates, and bacterial community structure (Anderson et al. 2015a). Photooxidation is not usually considered as a loss process for labile or semi-labile DOM in marine biogeochemical models (Anderson et al. 2015a). A novel feature in UniDOM is that, given the contribution of CDOM, we assume that the A state variable is subject to photooxidation by UV. Rather than having two state variables, however, we instead assume that a fixed fraction of the total autochthonous pool is present as CDOM. In common with most ocean models, the formation of aggregates (TEP) is not included as a loss process for DOC in UniDOM (Anderson et al. 2015a).

It is important that UniDOM is amenable to linking with soil models in order to generate input fluxes of $\mathrm{T}_{1}$ and $\mathrm{T}_{2}$. Compounds that may be classified as $\mathrm{T}_{1}$ tend to be retained in the mineral soil layers through adsorption to mineral surfaces and co-precipitation (Kaiser and Kalbitz 2012). They are therefore typically released from topsoil during high rainfall events (Raymond and Saiers 2010) as relatively 'young' substrates, i.e., derived from photosynthetically fixed carbon during the last 20-30 years (Tipping et al. 2012). Older, but functionally similar, compounds may also be released due to ecosystem modifications such as drainage (Evans et al. 2014), cultivation and urbanisation (Butman et al. 2014), or permafrost melting (Neff et al. 2006). Fraction $\mathrm{T}_{2}$, on the other hand, is less susceptible to immobilisation and so a higher proportion percolates downwards through the soil profile. It therefore accrues from base flow emanating from the deep (mineral) soil layers, as well as being released during rapid flow events (Ward et al. 2012; Pereira et al. 2014). Man-made release of DOM into freshwaters and estuaries, notably from sewage, is an issue in many countries. For the sake of simplicity (avoiding the use of an additional state variable), we suggest that this DOM is assigned as $\mathrm{T}_{2}$ to fit with the strongly versus weakly UV-absorbing scheme for separating terrigenous organic matter. 


\section{Data}

Fractions $T_{1}$ and $T_{2}$ should be amenable to measurement in order for UniDOM to link with observational programmes and field data. Here, we recommend the suitability of $\mathrm{SUVA}_{254}$ (mass-specific absorbance at $254 \mathrm{~nm}$ ), due to its widespread measurement and use in the DOM literature. The approach involves a 2-component end-member calculation, noting that it can only be an approximation given the variability in the functional and optical composition of DOM (Her et al. 2003). Briefly, a two-component description of DOM is consistent with the monotonic relation observed for diverse sample of freshwater DOM between the ratio of absorbance at two UV wavelengths, and specific absorbance at the upper wavelength (for further details, see Supplementary Appendix 2). This feature of DOM absorbance spectra has been used to generate accurate predictions of DOC concentration for independent, globally diverse samples in which terrigenous DOM predominates (Thacker et al. 2008; Tipping et al. 2009; Carter et al. 2012). The SUVA 254 end members employed are derived from a variety of empirical experimental and environmental data, a full description of which is given in Supplementary Appendix 2. They have values of $7.7 \mathrm{~L} \mathrm{mg} \mathrm{C}^{-1} \mathrm{~m}^{-1}$ for $100 \% \quad \mathrm{~T}_{1}$, and $1.8 \mathrm{~L} \mathrm{mg} \mathrm{C}^{-1} \mathrm{~m}^{-1}$ for $100 \% \mathrm{~T}_{2}$, in which case the $\mathrm{T}_{1}$ proportion of DOC, $\mathrm{f}_{\mathrm{T} 1}$, is:

$\mathrm{f}_{\mathrm{T} 1}=0.1695 \mathrm{SUVA}_{254}-0.3051$

Estimates of $T_{1}$ and $T_{2}$ based on $\mathrm{SUVA}_{254}$ for four large UK river catchments - the Avon, Tamar, Conwy and Halladale-are presented in Table 1, in order to demonstrate the feasibility of using field data to derive these fractions, as well as to provide a means of initialising the model. Sampling took place on the freshwater edge of the tidal limits. It is unsurprising that these rivers have contrasting $\mathrm{T}_{1}: \mathrm{T}_{2}$ ratios because their catchments differ in the relative proportions of major soil types, i.e., from a dominance of peats through to arable land covers, the latter providing a proxy for mineral soil coverage. Sampling was undertaken monthly from January to December 2017. For comparison, the data are accompanied by estimates for two headwaters catchments within the Conwy River system with contrasting peat cover, sampled monthly in the 2011 and 2012 hydrologic years (October to September). Laboratory analysis was undertaken for DOC concentration and UV absorbance, permitting the calculation of SUVA 254 . For further details, see Supplementary Appendix 1. Results demonstrate the utility of $\mathrm{SUVA}_{254}$ for estimating the $\mathrm{T}_{1}$ fraction, $\mathrm{f}_{\mathrm{T} 1}$, and show that there is considerable variability between sites. The highest $T_{1}$ fraction, $\mathrm{f}_{\mathrm{T} 1}=0.65$, is seen at Afon Ddu, where soils are almost entirely dominated by peat. In contrast, $\mathrm{f}_{\mathrm{T} 1}=0.13$, the lowest estimate, is seen for the Avon, which is largely bounded by mineral soils.

\section{Mathematical realisation}

A full mathematical version of UniDOM is now presented. Differential equations are described in this section for $T_{1}, T_{2}$ and $A$, along with lists of model variables and parameters in Tables 2 and 3. The very act of seeking out mathematical parameterisations of the various processes of DOM turnover is itself conducive to revealing conceptual insights. When we initially constructed UniDOM, constant rates were assigned to DOC turnover via microbes and photooxidation, as is common practice (at least for the former) in many models of DOM (Anderson et al. 2015a). Recent empirical evidence, however, suggests that average turnover rates should decline with time, i.e., with DOM age, because biologically and photochemically labile compounds are progressively removed from solution, leaving recalcitrant ones behind (Catalán et al. 2016; Evans et al. 2017). A novel feature of UniDOM is that the decline in DOC turnover rate with age, $\varphi_{\mathrm{L}}$, is described by:

$\varphi_{L}=\frac{1}{L^{\alpha}}=L^{-\alpha}$

where parameter $\alpha$ defines the rate of decline. Note that this relationship is invalid for $\mathrm{L}=0$ (division by zero). The solution is to truncate at $\mathrm{L}=\mathrm{L}_{0}$ (the age at which $\varphi_{\mathrm{L}}$ starts to decline) giving:

$$
\begin{aligned}
& \varphi_{L}=f_{L}\left(L_{0}, \alpha\right)=\left(L-L_{0}+1\right)^{-\alpha}, \mathrm{L}>\mathrm{L}_{0} \\
& \varphi_{L}=f_{L}\left(L_{0}, \alpha\right)=1, \mathrm{~L} \leq \mathrm{L}_{0}
\end{aligned}
$$

The predicted decline in $\varphi_{\mathrm{L}}$ with age (Eqs. 3a, 3b) is shown in Fig. 2, for $\alpha=0.38$, showing $\varphi_{\mathrm{L}}=1$, $0.23,0.17$ and 0.09 at $1,50,100$ and 500 days, respectively. Extending to longer timescales (not 
Table 1 Mean annual DOC concentration $\left(\mathrm{mg} \mathrm{L}^{-1}\right), \mathrm{SUVA}_{254}$ $\left(\mathrm{L} \mathrm{mg} \mathrm{C}{ }^{-1} \mathrm{~m}^{-1}\right.$ ) and $\mathrm{T}_{1}$ proportion $\left(\mathrm{f}_{\mathrm{T} 1}\right)$, along with catchment area $\left(\mathrm{km}^{2}\right)$, peat $\%$ and arable $\%$, for four large UK catchments at locations close to their tidal limits (Avon, $50.747^{\circ} \mathrm{N}$, $-1.782^{\circ} \mathrm{E} ; \quad$ Tamar, $50.531^{\circ} \mathrm{N}, \quad-4.222^{\circ} \mathrm{E} ; \quad$ Conwy, $53.107^{\circ} \mathrm{N},-3.792^{\circ} \mathrm{E}$; Halladale, $\left.58.479^{\circ} \mathrm{N},-3.903^{\circ} \mathrm{E}\right)$ and two headwater catchments (Afon Ddu, 52.976 $\mathrm{N}$, $-3.835^{\circ} \mathrm{E}$; Maenan, $\left.53.171^{\circ} \mathrm{N},-3.800^{\circ} \mathrm{E}\right)$

\begin{tabular}{|c|c|c|c|c|c|c|c|}
\hline Catchment & DOC & SUVA $_{254}$ & $\mathrm{f}_{\mathrm{T} 1}$ & Area & Peat $\%$ & Pasture \% & Arable \% \\
\hline Avon & $3.7(1.5)$ & $2.56(0.55)$ & $0.13(0.09)$ & 1712 & 0 & 26 & 42 \\
\hline Tamar & $7.3(5.7)$ & $2.70(0.98)$ & $0.15(0.17)$ & 925 & 1 & 66 & 16 \\
\hline Conwy & $5.9(3.7)$ & $4.23(1.64)$ & $0.41(0.28)$ & 340 & 21 & 19 & 0 \\
\hline Halladale & $14.7(5.7)$ & $4.92(0.49)$ & $0.53(0.08)$ & 193 & 92 & 2 & 0 \\
\hline Afon Ddu & $16.8(4.4)$ & $5.61(0.65)$ & $0.65(0.11)$ & 1.3 & 99 & 0 & 0 \\
\hline Maenan & $4.8(1.8)$ & $3.43(0.44)$ & $0.28(0.07)$ & 5.0 & 0 & 87 & 3 \\
\hline
\end{tabular}

Values in parentheses denote $1 \mathrm{SD}$

Table 2 Model variables

\begin{tabular}{lll}
\hline Variable & Description & Unit \\
\hline $\mathrm{T}_{1}$ & Terrigenous DOC fraction 1 & $\mathrm{mmol} \mathrm{C} \mathrm{m}^{-3}$ \\
$\mathrm{~T}_{2}$ & Terrigenous DOC fraction 2 & $\mathrm{mmol} \mathrm{C} \mathrm{m}^{-3}$ \\
$\mathrm{~A}$ & Autochthonous DOC & $\mathrm{mmol} \mathrm{C} \mathrm{m}$ \\
$\mathrm{P}_{\text {soil }}$ & DOC release from soil & $\mathrm{mmol} \mathrm{C} \mathrm{m}$ \\
$\mathrm{R}_{\mathrm{F} 1}$ & Residence time, river & day \\
$\mathrm{R}_{\mathrm{F} 2}$ & Residence time, lake & day \\
$\mathrm{R}_{\mathrm{E}}$ & Residence time, estuary & day \\
$\mathrm{R}_{\mathrm{O}}$ & Residence time, ocean & day \\
$\mathrm{k}_{\mathrm{UV}}$ & UV attenuation & $\mathrm{m}^{-1}$ \\
$\phi$ & Photo-oxidation $\mathrm{T}_{1}$ & day \\
$\mathrm{z}_{\mathrm{col}}$ & Water column depth & $\mathrm{m}^{-1}$ \\
$\varphi_{\mathrm{L}}$ & Normalised decay rate & \\
$\mathrm{L}$ & DOM age & day \\
$\mathrm{PP}$ & Primary production & $\mathrm{mmol} \mathrm{C} \mathrm{m}^{-3}$ day $^{-1}$ \\
\hline
\end{tabular}

shown), $\varphi_{\mathrm{L}}=0.11,0.044$ and 0.018 at 1,10 and 100 years.

The value assigned to parameter $\alpha$ is based on two relationships shown graphically in Evans et al. (2017; Fig. 3a therein) where, using $\log -\log$ axes, DOC turnover rate is plotted against water residence time (a proxy for DOM age). The first is based on laboratory dark-incubation data (Catalán et al. 2016) and has a slope of -0.38 , representing microbial turnover but with no contribution from photooxidation. The second relationship is for 82 predominantly European and North American lakes and reservoirs with water residence times ranging from a week to 700 years. We fitted a slope of -0.76 to the linear part of the relationship. The data in both cases are for net DOC removal and therefore, especially in the case of the lake data, may underestimate turnover, and overestimate $\alpha$, because of in situ production of DOC (Köhler et al. 2013; Evans et al. 2017). We will investigate the sensitivity of UniDOM to the full range of $\alpha$, from $\alpha=0$ (no effect of DOC age on lability), to $\alpha=0.76$ (assumes that the entire decrease in reactivity across the age gradient in the lake input-output dataset is due to declining reactivity, with no offset due to production), using an average value, $\alpha=0.38$, as standard.

The differential equation for $T_{1}$ involves production via soil and loss terms for photo-oxidation, flocculation and microbial decomposition:

$\begin{aligned} \frac{d T_{1}}{d t}= & \sigma_{T 1} P_{\text {soil }}-f_{L}\left(L_{0}, \alpha_{\text {pox }}\right) \emptyset\left(\emptyset^{r e f}, z_{c o l}, k_{U V}\right) T_{1} \\ & -\gamma_{X} T_{1}^{2}-f_{L}\left(L_{0}, \alpha_{\text {mic }}\right) \eta_{1} T_{1}+h\left(z_{c o l}\right) T_{1}\end{aligned}$

Terrigenous DOC $\left(T_{1}+T_{2}\right)$ is produced via soils and released into headwater catchments (flux $\mathrm{P}_{\text {soil }}$; mmol $\mathrm{C} \mathrm{m}^{-3}$ day $^{-1}$ ). Fraction $\sigma_{\mathrm{T} 1}$ of this release is as $\mathrm{T}_{1}$ (remainder as $\mathrm{T}_{2}$ ) and will vary for different soil types. Parameter $\sigma_{\mathrm{T} 1}$ was set as a weighted mean of data in Table 1 for the Avon and Tamar (mineral soil), Conwy (organic-mineral) and Halladale (organic), based on fractional cover in the UK of 43.7, 22.3 and $29.7 \%$ for organic, organic-mineral and organic soils, respectively (Bradley et al. 2005), giving $\sigma_{\mathrm{T} 1}=0.31$.

The second term in Eq. (4) is loss due to photooxidation that depends on a default maximum rate $\left(\phi^{\text {ref }}\right)$ that decays with time (Eqs. 3a, 3b) and the rate of UV attenuation with depth $\left(\mathrm{z}_{\mathrm{col}}, \mathrm{m}\right)$ according to the UV extinction coefficient $\left(\mathrm{k}_{\mathrm{UV}}, \mathrm{m}^{-1}\right)$. Parameter $\phi^{\text {ref }}$ can be estimated from measurements of DOC decay when 
Table 3 Model parameters

\begin{tabular}{|c|c|c|c|}
\hline Parameter & Description & Value & Unit \\
\hline$\sigma_{\mathrm{T} 1}$ & frac. $P_{\text {soil }}$ to $T_{1}$ & 0.31 & \\
\hline$\sigma_{\mathrm{A}}$ & frac. PP to A & 0.4 & \\
\hline$\phi^{\mathrm{ref}}$ & Photo-oxidation $\mathrm{T}_{1}$ : reference & 0.13 & day $^{-1}$ \\
\hline $\mathrm{k}_{\mathrm{UVw}}$ & UV attenuation: water & 0.12 & $\mathrm{~m}^{-1}$ \\
\hline $\mathrm{SUVA}_{350}$ & UV attenuation: DOC & 0.039 & $\mathrm{~m}^{2}(\mathrm{mmol} \mathrm{C})^{-1}$ \\
\hline$\xi$ & CDOM as fraction of $\mathrm{A}$ & 0.2 & \\
\hline$\beta$ & frac. photo-oxidation to $T_{2}$ or $A$ & 0.24 & \\
\hline$\gamma_{\mathrm{F}}$ & Flocculation DOC: freshwater & $2 \times 10^{-6}$ & $\left.\mathrm{day}^{-1}(\mathrm{mmol} \mathrm{C} \mathrm{m})^{-3}\right)^{-1}$ \\
\hline$\gamma_{\mathrm{E}}$ & flocculation DOC: estuaries & $2 \times 10^{-5}$ & day $\left.^{-1}(\mathrm{mmol} \mathrm{C} \mathrm{m})^{-3}\right)^{-1}$ \\
\hline$\gamma_{\mathrm{o}}$ & Flocculation DOC: ocean & $2 \times 10^{-6}$ & day $\left.^{-1}(\mathrm{mmol} \mathrm{C} \mathrm{m})^{-3}\right)^{-1}$ \\
\hline$\eta_{1}$ & Microbial turnover: $\mathrm{T}_{1}(\mathrm{~L}=0)$ & 0.013 & day $^{-1}$ \\
\hline$\eta_{2}$ & Microbial turnover: $\mathrm{T}_{2}(\mathrm{~L}=0)$ & 0.038 & day $^{-1}$ \\
\hline$\eta_{\mathrm{A}}$ & Microbial turnover: A & 0.012 & day $^{-1}$ \\
\hline$\alpha$ & Decay parameter for turnover & 0.38 & \\
\hline $\mathrm{L}_{0}$ & Truncation point for DOM age & 1.0 & day \\
\hline $\mathrm{PP}_{0}$ & Primary production at surface & 1.4 & mmol C m ${ }^{-3}$ day $^{-1}$ \\
\hline $\mathrm{k}_{\mathrm{PAR}}$ & Attenuation of PAR with depth & 0.046 & $m^{-1}$ \\
\hline
\end{tabular}
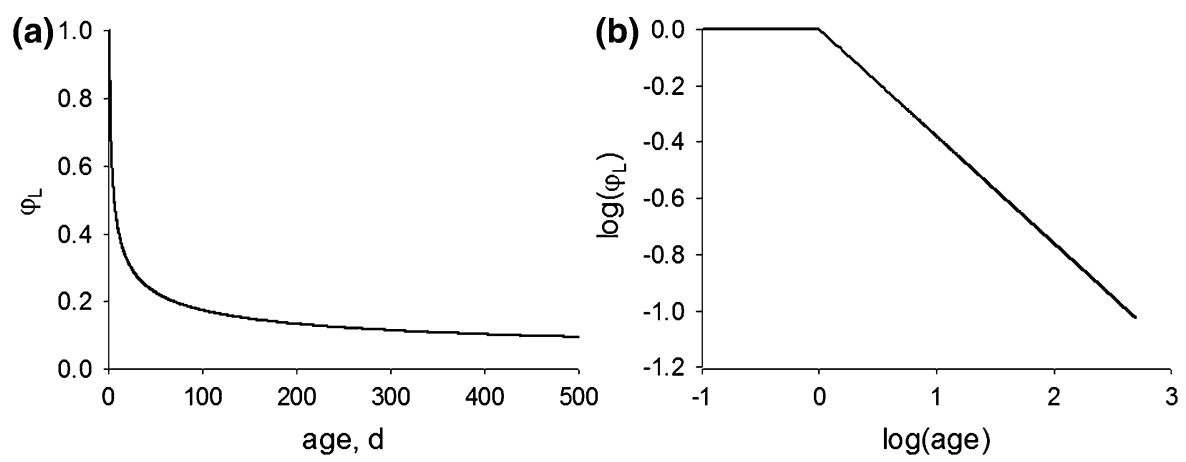

Fig. 2 Predicted decline in normalised DOC turnover $\left(\varphi_{\mathrm{L}}\right)$ with age (L) for $\alpha=0.38$ and $\mathrm{L}_{0}=1$ day: a linear axes, $\mathbf{b}$ log axes (slope for $\log ($ age $)>0$ is -0.38$)$

exposed to UV irradiation: $14 \%$ decrease over $8 \mathrm{~h}, \phi$ $=0.22$ day $^{-1}$ (Bertilsson and Tranvik 1998; Swedish Lakes), $40 \%$ over 21 days, $\phi=0.025$ day $^{-1}$ (Shiller et al. 2006; Mississippi River), 84\% over 67 days, $\phi$ $=0.043$ day $^{-1}$ (Helms et al. 2013; North Pacific water), $81 \%$ over 110 days, $\phi=0.028$ day $^{-1}$ (Helms et al. 2014; Chesapeake, USA) and 50\% over 1 day, $\phi$ $=0.35$ day $^{-1}$ (Gonsior et al. 2014; oligotrophic ocean waters). These $\phi$ values were calculated by integrating Eqs. (3a, 3b), with $\alpha=0.38$, assuming that half the loss is due to photooxidation and calculating the rate at $\mathrm{t}=1$ day $\left(=\mathrm{L}_{0}\right)$. We use an average of these values, $\phi^{\text {ref }}=0.13 \mathrm{day}^{-1}$, noting that all are from low latitude sites except Bertilsson and Tranvik (1998).

Attenuation of UV-B, the most photo-active part of the spectrum, is strong in natural waters (Graneli et al. 1996) and can be described by Beer's Law. The extinction coefficient $\mathrm{k}_{\mathrm{UV}}\left(\mathrm{m}^{-1}\right)$ was derived using a typical z $10 \%$ (depth at which $10 \%$ of UV remains) for open ocean waters of $20 \mathrm{~m}$ (Tedetti and Sempéré 2006), which gives a rate of extinction of $0.12 \mathrm{~m}^{-1}$ (parameter $\mathrm{k}_{\mathrm{UV}_{\mathrm{w}}}$ ). The rate of $\mathrm{UV}$ extinction increase with DOC concentration can be described from SUVA $_{350}$, which is the specific UV absorption at 
$350 \mathrm{~nm}$ per unit DOC $\left(\mathrm{m}^{2}(\mathrm{mmol} \mathrm{C})^{-1}\right.$; Massicotte et al. 2017), in which case $\mathrm{k}_{\mathrm{UV}}$ is:

$k_{U V}=k_{U V w}+S U V A_{350}\left(T_{1}+\xi A\right)$

Note that a fraction of autochthonous DOM, $\xi$, is also assumed to absorb UV (see below). A typical value of $\mathrm{SUVA}_{350}$ for freshwater systems is $1.0 \mathrm{~m}^{2}$ $\left(\mathrm{g} \mathrm{C}^{-1}\right.$ (Massicotte et al. 2017), which is equivalent to $\left.0.012 \mathrm{~m}^{2}(\mathrm{mmol} \mathrm{C})^{-1}\right)$. This value is for total DOC and so, if instead normalised to $\mathrm{T}_{1}$, then a typical value could be $0.039 \mathrm{~m}^{2}(\mathrm{mmol} \mathrm{C})^{-1}$, assuming that $\mathrm{T}_{1}$ is a $31 \%$ of the total (parameter $\sigma_{\mathrm{T} 1}$ ). For example, this value of $\mathrm{SUVA}_{350}$, combined with $\mathrm{k}_{\mathrm{UVw}}=0.12 \mathrm{~m}^{-1}$, gives an extinction, $\mathrm{k}_{\mathrm{UV}}$, of $7.92 \mathrm{~m}^{-1}$ for a DOC concentration of $200 \mathrm{mmol} \mathrm{m}^{-3}$, meaning that $55 \%$ of $\mathrm{UV}$ is attenuated at $0.1 \mathrm{~m}$ and $98 \%$ at $0.5 \mathrm{~m}$. The average rate of photo-oxidation within a water column of depth $\mathrm{z}_{\mathrm{col}}(\mathrm{m}), \phi\left(\phi^{\mathrm{ref}}, \mathrm{z}_{\mathrm{col}}, \mathrm{k}_{\mathrm{UV}}\right)$ is then:

$\emptyset\left(\phi^{r e f}, z_{c o l}, k_{U V}\right)=\frac{\emptyset^{r e f}}{z_{c o l}} \int_{0}^{z_{c o l}} e^{-k_{U V} z} d z$

$\int_{0}^{z_{c o l}} e^{-k_{U V} z} d z=\frac{1}{k_{U V}}-\frac{e^{-k_{U V} z_{c o l}}}{k_{U V}}$

Flocculation is assumed only to apply to fraction $\mathrm{T}_{1}$, given that aromatic compounds are prone to removal from solution via sorption and co-precipitation with reactive minerals (Vilge-Ritter et al. 1999; Riedel et al. 2012). After due consideration, we concluded that a mechanistic model of flocculation involving electrostatic chemistry, molecular interactions, turbulent mixing, etc., is not practically feasible, especially across the entire LOAC, because of the difficulties of reliable parameterisation. Unlike microbial turnover and photooxidation, we resorted to the application of different flocculation rates in freshwater $(F)$, estuaries (E) and the ocean $(O)$, parameters $\gamma_{F}, \gamma_{E}$ and $\gamma_{\mathrm{O}}$, calculated as a square function of $T_{1}$ (encounter rates between molecules increase with density). A flocculation rate of $0.05 \mathrm{day}^{-1}$ for estuaries was observed by Asmala et al. (2014) at a salinity of 1 (DOC declined from 15.0 to $14.3 \mathrm{mg} \mathrm{L}^{-1}$ over $24 \mathrm{~h})$. This therefore equates to $0.05 / 1250(15 \mathrm{mg}$ $\mathrm{L}^{-1}=1250 \mathrm{mmol} \mathrm{C} \mathrm{m}^{-3}$ ), giving $\gamma_{\mathrm{E}} \approx 4.0 \times 10^{-5}$ day $\left.^{-1}(\mathrm{mmol} \mathrm{C} \mathrm{m})^{-3}\right)^{-1}$. The extent of flocculation may, however, be highly variable from site to site. In some cases, DOC shows conservative behaviour in estuaries, with little turnover (e.g., Mantoura and
Woodward 1983). We tentatively set $\gamma_{\mathrm{E}-}$ $\left.\approx 2.0 \times 10^{-5} \mathrm{day}^{-1}(\mathrm{mmol} \mathrm{C} \mathrm{m})^{-3}\right)^{-1}$, a value half way between zero and that derived from Asmala et al. (2014), recognising that there is considerable uncertainty in this parameter. The flocculation rate for lakes was assigned a value of $0.0002 \mathrm{day}^{-1}\left(\mathrm{~g} \mathrm{~m}^{-3}\right)^{-1}$ by Tipping et al. (2016); converting units gives $\gamma_{\mathrm{F}-}$ $=2 \times 10^{-6}$ day $^{-1}(\mathrm{mmol} \mathrm{C} \mathrm{m})^{-3}$. We tentatively set the flocculation parameter for the ocean to the same value, i.e., $\gamma_{O}=2 \times 10^{-6}$ day $^{-1}$, while noting that realised rates will be much lower because of the lower concentrations involved. The formation of transparent exopolymer particles (TEP) by particle aggregation is not included in UniDOM, as is the case for most marine ecosystem models.

The third loss term in Eq. (4) is DOC utilisation by bacteria to fuel growth and metabolism. The rate of microbial degradation at time 1 day $\left(\mathrm{L}_{0}=1\right)$ was estimated from the linear relationship for dark incubation experiments shown in Evans et al. (2017; their Fig. 3a, dashed line), giving $0.03 \mathrm{day}^{-1}$ (note that Catalán et al. (2016) show data with the same relationship for residence time as low as 1 day). Separate decay rates are specified for $\mathrm{T}_{1}$ and $\mathrm{T}_{2}$. We assume that microbial degradation of fraction $T_{1}$ is slow because of its high lignin content and thus use a value $1 / 3$ for that of fraction $T_{2}$ based on a comparison of bacteria respiration rates in peat-influenced water versus clear mountain waters (Berggren and del Giorgio 2015). If the ratio of $\mathrm{T}_{2}: \mathrm{T}_{1}$ is 69:31 (parameter $\left.\sigma_{\mathrm{T} 1}=0.31\right)$ and the average rate is $0.03 \mathrm{day}^{-1}$, then $\eta_{1}=0.013$ day $^{-1}$ (for $T_{1}$ ) and $\eta_{2}=0.038$ day $^{-1}$ (for $\left.\mathrm{T}_{2}\right)$. Finally, $\mathrm{h}\left(\mathrm{z}_{\mathrm{col}}\right)$ calculates changes in concentration as $T_{1}$ is diluted when the depth of the water column increases as water moves from rivers to the estuary and the ocean (see next section).

The differential equation for state variable $T_{2}$, is:

$$
\begin{aligned}
\frac{d T_{2}}{d t}= & \left(1-\sigma_{T 1}\right) P_{\text {soil }} \\
& +f_{L}\left(L_{0}, \alpha_{\text {pox }}\right) \beta \emptyset\left(\phi^{r e f}, z_{c o l}, k_{U V}\right) T_{1} \\
& -f_{L}\left(L_{0}, \alpha_{\text {mic }}\right) \eta_{2} T_{2}+h\left(z_{c o l}\right) T_{2}
\end{aligned}
$$

A fraction, $\beta$, of photo-oxidised $\mathrm{T}_{1}$ is allocated to $\mathrm{T}_{2}$ (the remainder is lost as $\mathrm{CO}_{2}$ ), with an assigned value of 0.24 (e.g., Medeiros et al. 2015; Mostovaya et al. 2016). There is assumed to be no flocculation of $T_{2}$.

Our main focus is the turnover of terrigenous DOC (fractions $\mathrm{T}_{1}, \mathrm{~T}_{2}$ ) and so we adopt a simple description of the autochthonous fraction, $\mathrm{A}$, which completes the 
representation of bulk DOC in UniDOM. It is possible to describe autochthonous DOC production in terms of a range of processes including phytoplankton exudation, zooplankton "messy feeding", detritus turnover, etc., and to describe its turnover using separate pools such as labile, semi-labile and refractory (Anderson et al. 2015a). We use a single state variable, A, with production specified as a simple fraction, $\sigma_{\mathrm{A}}$, of primary production, and which is subject to microbial turnover and photooxidation as loss terms. The inclusion of photooxidation is a novel feature of UniDOM, introduced to provide consistency with the parameterisation of $\mathrm{T}_{1}$, given that a fraction of autochthonous DOC is coloured. Note that it is entirely possible for users of UniDOM to substitute the simple parameterisation of A presented herein with more complex representations of the autochthonous pool of DOC.

The equation for autochthonous DOC (A) is:

$\frac{d A}{d t}=\sigma_{A} P P-\phi\left(\phi^{r e f}, z_{c o l}, k_{U V}\right) \xi(1-\beta) A-\eta_{A} A$

where the terms are production and losses due to photooxidation and microbial consumption (note that $\mathrm{A}$ is unaffected by dilution: see next section). The ultimate source is primary production ( $\mathrm{PP}, \mathrm{mmol}$ $\mathrm{C} \mathrm{m}^{-3}$ day $^{-1}$ ) that occurs throughout the LOAC and is calculated from a surface rate, $\mathrm{PP}_{0}$, that is integrated over depth according to the attenuation coefficient, $\mathrm{k}_{\mathrm{PAR}}$ :

$P P=\frac{P P_{0}}{z} \int_{0}^{z_{c o l}} e^{-k_{P A R} z} \mathrm{dz}$

The calculation does not include PP from macrophytes and benthic algae in rivers. We use $\mathrm{PP}_{0-}$ $=1.4 \mathrm{mmol} \mathrm{C} \mathrm{m}^{-3} \mathrm{day}^{-1}$ based on primary production of $200 \mathrm{~g} \mathrm{C} \mathrm{m}^{-2}$ year $^{-1}$ for the North Sea (Capuzzo et al. 2018) and $\mathrm{k}_{\mathrm{PAR}}$ of $0.046 \mathrm{~m}^{-1}$. State variable $\mathrm{A}$ is assumed to have properties equivalent to those of the semi-labile pool in the ocean in terms of its production and biological turnover. Parameter $\sigma_{\mathrm{A}}$ is then calculated as semi-labile DOC normalised to oceanic PP, giving a value of 0.40 when derived from the model of Anderson and Ducklow (2001), assuming that $90 \%$ of non-phytoplankton release processes are semi-labile (Anderson and Williams 1998).
The first loss term in Eq. (9) represents photooxidation of CDOM in which, as for photo-oxidation of $\mathrm{T}_{1}$, fraction $\beta$ is returned to the DOC pool, hence only $(1-\beta)$ is lost to $\mathrm{CO}_{2}$. A novel aspect of the representation of autochthonous DOM in UniDOM is that a fixed fraction of $\mathrm{A}, \xi$, is assumed to be subject to photo-oxidation (Coble 2007); we use 20\%, i.e., $\xi=0.2$ (note that this fraction influences UV attenuation in surface waters and thereby influences the rate of degradation of $\mathrm{T}_{1}$ ). Semi-labile DOM turns over on seasonal timescales (e.g., Anderson and Williams 1999; Hansell 2013). A microbial degradation rate of 0.006 day $^{-1}$ at $0{ }^{\circ} \mathrm{C}$ was used by Tipping et al. (2016) when modelling macronutrient processing within temperate lakes, giving a mean residence time of $1 / 0.006=166$ days. We use $\eta_{\mathrm{A}}=0.012$ day $^{-1}$, assuming a typical temperature of $10{ }^{\circ} \mathrm{C}$ and a $\mathrm{Q}_{10}$ for temperature dependence of 2. Finally, the turnover rate of $\mathrm{A}$ is assumed not to decline with increasing DOM age, unlike fractions $T_{1}$ and $T_{2}$. It is not necessary to model the ageing fraction of autochthonous DOC in UniDOM, given our focus on fate of long-lived terrigenous DOM.

\section{Model setup}

The UniDOM model is tested in a simple physical framework that involves a three-phase representation of water movement from freshwater to estuary to coastal ocean (Fig. 3). Residence times are specified for each domain, $\mathrm{R}_{\mathrm{F} 1}, \mathrm{R}_{\mathrm{F} 2}, \mathrm{R}_{\mathrm{E}}$ and $\mathrm{R}_{\mathrm{O}}$ days for freshwater (rivers and lakes), estuaries and ocean, respectively. Water enters the freshwater domain at time $\mathrm{t}=0$, with initial concentrations for $\mathrm{T}_{1}$ and $\mathrm{T}_{2}$, and travels for $\mathrm{R}_{\mathrm{F}}$ days until it reaches the estuary. It is assumed that the major terrigenous inputs of DOC are from wet, uncultivated organic-rich soil types including peats. In our case study of UK waters, these occur predominantly in the upper reaches of catchments and so the current model configuration assumes that terrigenous DOC only enters the LOAC at time $t=0$, without further additions en route. This simplifying assumption will need to be modified if the model were applied to other areas of the world, e.g. when DOC-rich water is produced in lowland wetlands (e.g., Wiegner and Seitzinger 2004), or where non-peat DOC sources are proportionally more important. The 


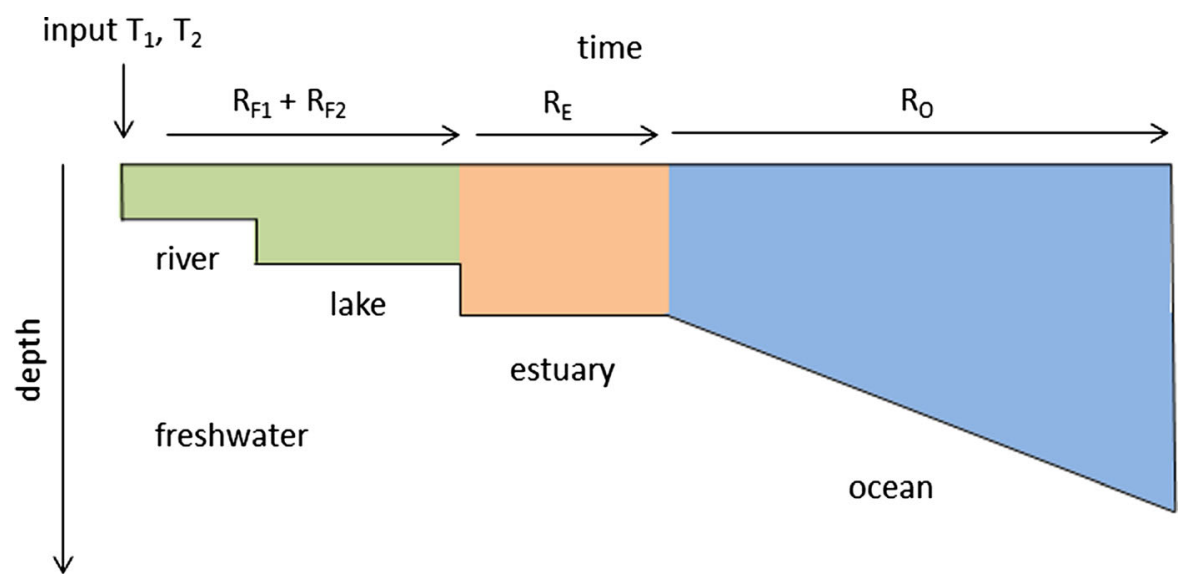

Fig. 3 Physical setup. $\mathrm{T}_{1}$ and $\mathrm{T}_{2}$ are input at time $\mathrm{t}=0$ and water then travels through freshwater, estuary and ocean with residence times $\mathrm{R}_{\mathrm{F} 1}+\mathrm{R}_{\mathrm{F} 2}, \mathrm{R}_{\mathrm{E}}$ and $\mathrm{R}_{\mathrm{O}}$. Autochthnous DOC, $\mathrm{A}$, is produced throughout the LOAC (not shown)

water then passes sequentially through the estuarine and ocean systems.

We use default residence times for UK waters of 1 , 0,3 and 730 days for $\mathrm{R}_{\mathrm{F} 1}, \mathrm{R}_{\mathrm{F} 2}, \mathrm{R}_{\mathrm{E}}$ and $\mathrm{R}_{\mathrm{O}}$, respectively (i.e., with no lakes; $R_{F 2}=109$ days will be examined separately). Residence times for UK rivers, without lakes or impoundments, range from hours to several days, e.g. Worrall et al. (2014) give a mean of $26.7 \mathrm{~h}$. They are highly variable for estuaries, often $<$ 3 days, although sometimes considerably longer (Uncles et al. 2002; Yuan et al. 2007). We use $\mathrm{R}_{\mathrm{E}}=3$ days, which is the median value of $34 \mathrm{UK}$ estuaries tabulated in Uncles et al. (2002). The 730 day residence time for the (coastal) ocean is, for our illustrative case study, representative of the North Sea, which directly or indirectly receives much of the DOM exported from the UK land mass (Painter et al. 2018) and where the age distribution of water varies between 0 and 4 years (Prandle 1984; Blaas et al. 2001). In a second simulation, we include an average lake residence time $\left(\mathrm{R}_{\mathrm{F} 2}\right)$ of 109 days, based on average properties of UK lakes obtained from the Centre for Ecology and Hydrology (CEH) database (https://eip.ceh.ac.uk/apps/lakes/), which gives a median retention time and depth of 108.8 days and $4.42 \mathrm{~m}$, respectively.

Depths are assigned for the freshwater system $\left(\mathrm{z}_{\mathrm{F} 1}\right.$ and $\mathrm{z}_{\mathrm{F} 2}$ for rivers and lakes) and the estuary $\left(\mathrm{z}_{\mathrm{E}}\right)$. We use a river depth, $\mathrm{z}_{\mathrm{F} 1}$, of $1 \mathrm{~m}$ (e.g., see National River Flow Archive: http://nrfa.ceh.ac.uk/), $\mathrm{z}_{\mathrm{F} 2}$ of $4 \mathrm{~m}$ (see above) and an estuary depth of $10 \mathrm{~m}$ (e.g., Prandle and
Lane 2015). Whenever depth increases, e.g., as water enters the estuary, $T_{1}$ and $T_{2}$ are diluted assuming that the diluting water has zero concentrations of these variables. Fraction A is assumed to be present in all waters and so there is no dilution. Maximum ocean depth, $\mathrm{z}_{\mathrm{O}}$, is set to $100 \mathrm{~m}$, which is a characteristic value for the North Sea (Blaas et al. 2001), with an assumed linear taper from $\mathrm{z}_{\mathrm{E}}$ to $\mathrm{z}_{\mathrm{O}}$ throughout period $\mathrm{R}_{\mathrm{O}}$ (Fig. 3).

The complications of modelling DOC release from soils and its entry into freshwater are avoided by setting initial concentrations of $\mathrm{T}_{1}$ and $\mathrm{T}_{2}$ at time $\mathrm{t}=0$. If a typical DOC concentration in catchment water is $674 \mathrm{mmol} \mathrm{m}^{-3}$ (based on a weighted average of the values in Table 1 , as for $\sigma_{\mathrm{T} 1}$ ) and $\sigma_{\mathrm{T} 1}=0.31$, then $\mathrm{T}_{1}$ and $\mathrm{T}_{2}$ are 209 and $465 \mathrm{mmol} \mathrm{C} \mathrm{m}^{-3}$ respectively. Fraction $\mathrm{T}_{2}$ is also generated throughout the LOAC by photooxidation of $\mathrm{T}_{1}$ (the second term in Eq. 8). This newly produced $\mathrm{T}_{2}$ is assumed to have a "reactivity age", L, of zero. A cohort approach is therefore employed whereby a new state variable for $T_{2}$ is created for each model day. The model is coded in $\mathrm{R}$, using the EMPOWER ecosystem model testbed (Anderson et al. 2015b; see this reference for information about the structure of the code, input and output files, and instructions for use). The UniDOM code, including supporting files, is listed in Supplementary Appendix 3. 

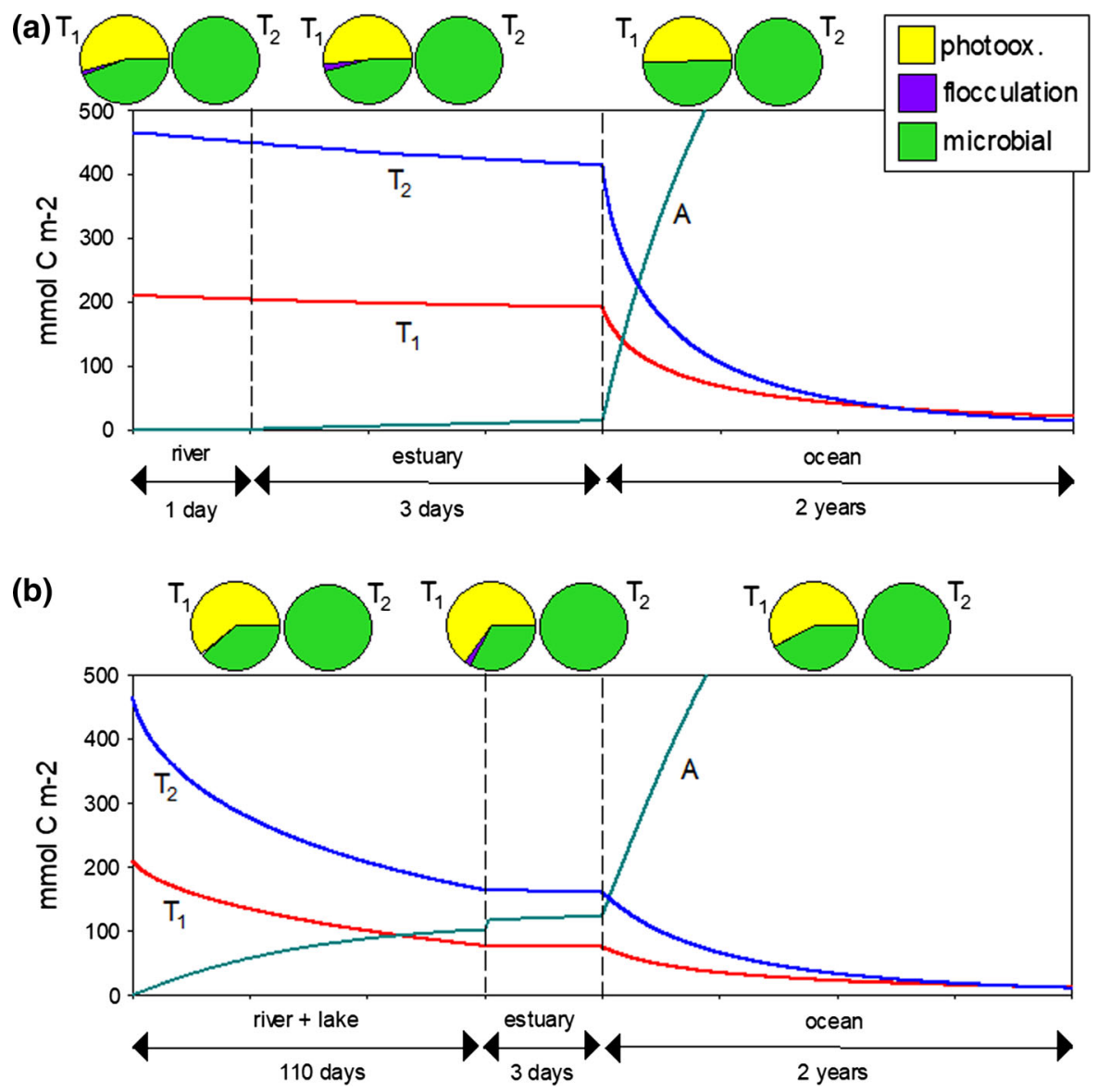

Fig. 4 Predicted quantities of $\mathrm{T}_{1}, \mathrm{~T}_{2}$ and $\mathrm{A}\left(\mathrm{mmol} \mathrm{C} \mathrm{m} \mathrm{m}^{-2}\right)$ across the LOAC, with relative contributions of photooxidation, flocculation and microbial turnover shown in pie

\section{Results}

Predicted quantities of $\mathrm{T}_{1}, \mathrm{~T}_{2}$ and $\mathrm{A}\left(\mathrm{mmol} \mathrm{C} \mathrm{m}{ }^{-2}\right)$ across the LOAC, with residence times of 1,3 and 730 days for freshwater, estuary and ocean, respectively, are shown in Fig. 4. Note that results are shown on a depth-integrated basis $\left(\mathrm{m}^{-2}\right)$ because the decrease in terrigenous DOC over time is then solely determined by DOC loss processes, whereas concentration units $\left(\mathrm{m}^{-3}\right)$ are also affected by dilution as the water column deepens. Relatively little degradation of DOC is predicted over the first 4 days (i.e., by the time water exits the estuary), with $\mathrm{T}_{1}$ declining from 209 to $191 \mathrm{mmol} \mathrm{C} \mathrm{m}^{-2}$, and $\mathrm{T}_{2}$ from 465 to $414 \mathrm{mmol} \mathrm{C} \mathrm{m}^{-2}$, after 4 days (Fig. $4 \mathrm{a}$ ). Photooxidation, flocculation and microbial consumption accounted for 52.6, 2.0 and $45.4 \%$ of turnover of $\mathrm{T}_{1}$, charts: a residence times $R_{F 1}$ (river) 1 day, $R_{F 2}=0, R_{E}$ (estuary) 3 days, $\mathrm{R}_{\mathrm{O}}$ (ocean) 2 years, $\mathbf{b} \mathrm{R}_{\mathrm{F} 1}=1$ day, $\mathrm{R}_{\mathrm{F} 2 \text { - }}$ $=109$ days (lake), $R_{E}=3$ days, $R_{O}=2$ years

respectively, while microbes were the sole loss term for fraction $T_{2}$. The longer residence time in the ocean led to greater removal, with $\mathrm{T}_{1}$ decreasing to 40.5 and $20.2 \mathrm{mmol} \mathrm{C} \mathrm{m}^{-2}$, and $\mathrm{T}_{2}$ to 46.7 and $13.3 \mathrm{mmol} \mathrm{C} \mathrm{m}^{-2}$, after 1 and 2 years of ocean transit, respectively. Thus, after 2 years in the ocean, predicted terrigenous DOC is $33.5 \mathrm{mmol} \mathrm{C} \mathrm{m}^{-2}$, i.e., equivalent to $5.0 \%$ of the DOC released into catchment waters. Photooxidation again accounted for the majority of the loss of $\mathrm{T}_{1}(50.2 \%)$, with $49.7 \%$ from microbial turnover and only $0.1 \%$ from flocculation. Predicted concentrations of $T_{1}$ and $T_{2}$ after 2 years in the ocean are 0.20 and $0.13 \mathrm{mmol} \mathrm{C} \mathrm{m}^{-3}$, within a water column $100 \mathrm{~m}$ deep. Autochthonous DOM (A) was produced throughout the LOAC, leading to a concentration of $1.4 \mathrm{mmol} \mathrm{C} \mathrm{m}^{-3}$ exiting the estuary (after 4 days) and $9.0 \mathrm{mmol} \mathrm{C} \mathrm{m}^{-3}$ after 2 years 
in the ocean. Microbial consumption accounted for $86.9 \%$ of turnover of autochthonous DOM, with the remaining $13.1 \%$ due to photooxidation.

The inclusion of a lake with a 109-day residence time led to a much greater decrease in predicted DOC within the freshwater domain, with predicted $\mathrm{T}_{1}$ and $\mathrm{T}_{2}$ at day 110 of 75.1 and $162.7 \mathrm{mmol} \mathrm{C} \mathrm{m}^{-2}$, respectively (Fig. 4b). The percentage losses of $\mathrm{T}_{1}$ and $\mathrm{T}_{2}$ are almost equal: $64 \%$ versus $65 \%$. Predicted quantities of $\mathrm{T}_{1}$ and $\mathrm{T}_{2}$ further declined to 10.8 and $9.7 \mathrm{mmol} \mathrm{C} \mathrm{m}{ }^{-2}$, respectively, after 2 years of oceanic transit.

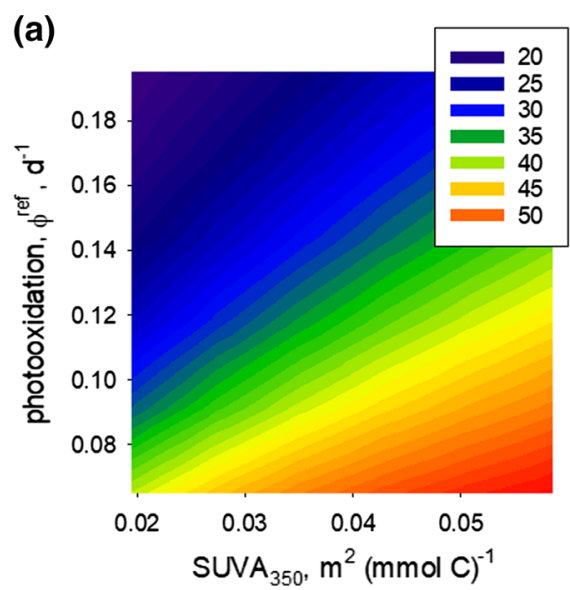

Sensitivity analysis was carried out by varying model parameters $\pm 10 \%$, focusing on predicted terrigenous DOC $\left(T_{1}+T_{2}\right)$ after 734 days (residence times as in Fig. 4a; the standard output, i.e., with parameters as in Table 2, is $\left.20.2+13.3=33.5 \mathrm{mmol} \mathrm{C} \mathrm{m}^{-2}\right)$. Only six parameters showed sensitivity $>5 \%$ (i.e., $\mathrm{T}_{1}+\mathrm{T}_{2}$ at day 734 changed by $\pm 5 \%$ or more): $\sigma_{\mathrm{T} 1}$ (initial $\mathrm{T}_{1}$ as fraction of $\mathrm{T}_{1}+\mathrm{T}_{2}$ ), photooxidation parameters $\phi^{\text {ref }}$ (default rate) and SUVA $_{350}$ (attenuation of UV due to coloured DOM), the microbial decay rates of $T_{1}$ and $T_{2}\left(\eta_{1}, \eta_{2}\right)$ and $\alpha$ (age-related decline in turnover). The sensitivity of predicted terrigenous DOC $\left(\mathrm{T}_{1}+\mathrm{T}_{2}\right)$ after 2 years

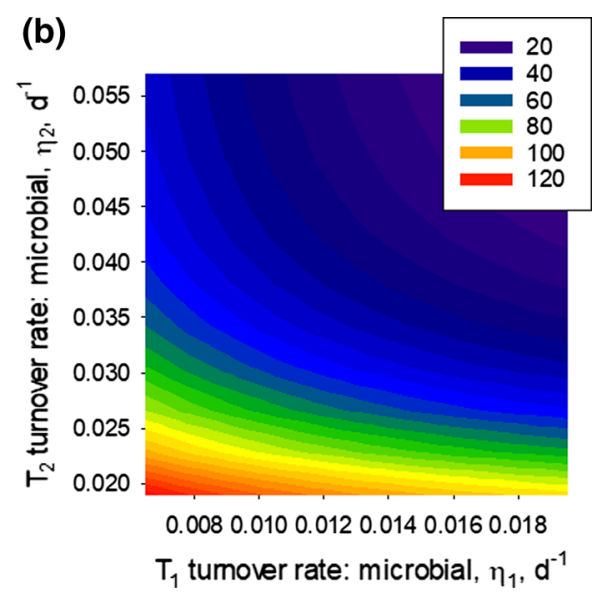

Fig. 5 Predicted $T_{1}+T_{2}$ at day 734 as influenced by a photooxidation parameters $\phi^{\text {ref }}$ (default rate) and SUVA 350 (UV attenuation due to DOM) and $\mathbf{b}$ microbial degradation rates (parameters $\eta_{1}$ and $\eta_{2}$ for $T_{1}$ and $T_{2}$ respectively; at $L=0$ )

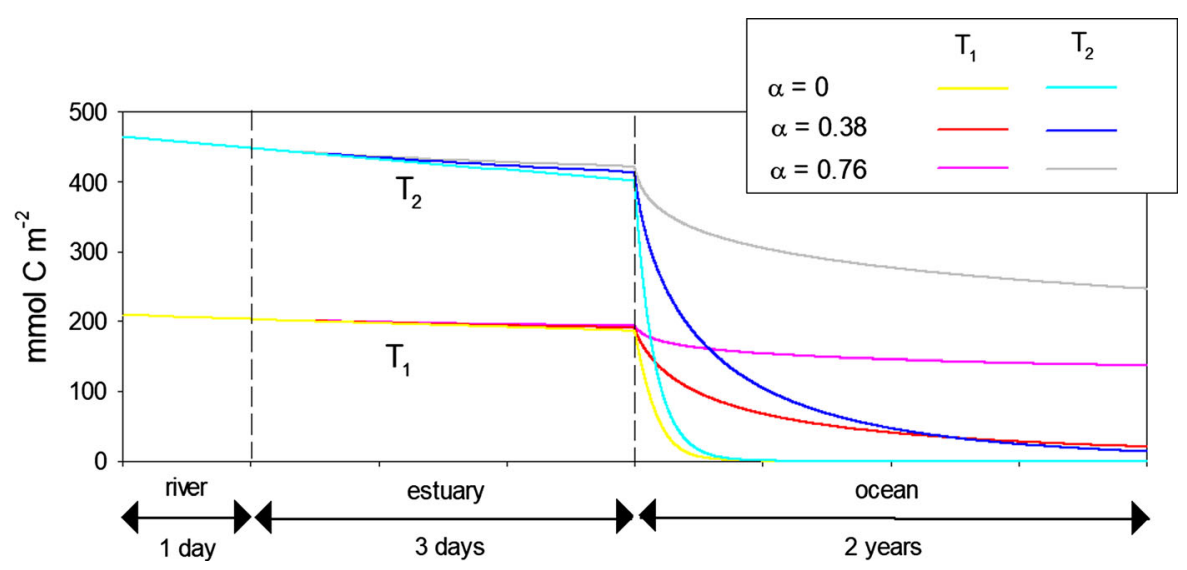

Fig. 6 Model sensitivity of predicted $\mathrm{T}_{1}$ and $\mathrm{T}_{2}$ to rates of decline of photooxidation and microbial degradation (parameter $\alpha$; default is $\alpha=0.38$ ). Residence times are as for Fig. 4a (i.e., without the inclusion of lakes) 
in the ocean (day 734, with residence times as in Fig. 4a) to parameters $\phi^{\text {ref }}, \operatorname{SUVA}_{350}, \eta_{1}$ and $\eta_{2}$ is shown in Fig. 5. Decreasing the rate of photooxidation and/or increasing SUVA $_{350}$ (leading to faster attenuation of UV in the water column and so less photooxidation; note that there is no link between parameters $\mathrm{SUVA}_{350}$ and $\phi^{\text {ref }}$ in the model) results in predicted terrigenous DOC increasing from the standard value of $33.5 \mathrm{mmol} \mathrm{C} \mathrm{m}^{-2}$ (default parameters) to values over $50 \mathrm{mmol} \mathrm{C} \mathrm{m}^{-2}$ (Fig. 5a). Even larger quantities were predicted in response to lowering rates of microbial consumption, with DOC $>120 \mathrm{mmol} \mathrm{C} \mathrm{m}^{-2}$ (Fig. 5b). Sensitivity is high for parameter $\eta_{2}$ because microbial consumption is the sole loss term for fraction $\mathrm{T}_{2}$.

A key feature of UniDOM is that decay rates due to photooxidation and microbial degradation decline over time because $T_{1}$ and $T_{2}$ are assumed to become progressively more recalcitrant with increasing age. Model sensitivity to the parameter that controls this decline, $\alpha$, led to dramatic changes in predicted fluxes of DOC across the LOAC (Fig. 6). Setting $\alpha=0$ means that parameters $\phi^{\text {ref }}, \eta_{1}$ and $\eta_{2}$ remain fixed, independent of DOM age, at their default values of $0.13,0.013$ and 0.038 day $^{-1}$, respectively. In this case, predicted terrigenous DOC declined to $<1 \%$ of the initial $674 \mathrm{mmol} \mathrm{C} \mathrm{m} \mathrm{m}^{-2}$ by day 129 , to $<0.01 \%$ by day 266 , with only a trace $\left(\approx 10^{-6} \mathrm{mmol} \mathrm{C} \mathrm{m}^{-2}\right)$ left by day 734 . In contrast, $\alpha=0.76$ (i.e., a rapid decline in degradation rates with DOM age) gives rise to relatively little degradation over the entire LOAC, with predicted $\mathrm{T}_{1}$ and $\mathrm{T}_{2}$ of 137 and $246 \mathrm{mmol} \mathrm{C} \mathrm{m}{ }^{-2}$ remaining after 734 days.

\section{Discussion}

Our main aim of developing UniDOM was to highlight knowledge gaps regarding the turnover of DOC across the LOAC, from which to present new ideas to progress this field of research. Understanding DOC turnover is an ongoing challenge for scientists because DOC consists of a plethora of compounds that differ in their reactivity and residence times, and which undergo extensive transformations during transport within rivers, estuaries and the ocean (Hopkinson et al. 1998; Geeraert et al. 2016). Furthermore, the concept of turnover (lability) is a complex one, involving biochemical structure, substrate concentration, presence/absence of competing substrates, microbial requirements (and hence microbial community composition) and the presence or absence of light (Anderson et al. 2015a).

Terrigenous DOC is subject to several turnover processes as it transits the LOAC-microbial consumption, photooxidation and flocculation-and the relative influence of these processes may vary considerably across freshwaters, estuaries and the ocean. Many models use a single state variable to represent terrigenous DOM (e.g., Futter et al. 2007; Rowe et al. 2014; Tipping et al. 2016), whereas we suggest that at least two are required to capture the complexity of DOC cycling across the LOAC. A novel feature of UniDOM is that terrigenous DOC is divided into two pools, $T_{1}$ and $T_{2}$, based on UV-absorbance (essentially, coloured and non-coloured). Fraction $T_{1}$ is strongly UV-absorbing and so prone to photooxidation as well as flocculation, but relatively resistant to microbial consumption, whereas $T_{2}$ is weakly or not UV-absorbing, is not prone to photooxidation and flocculation and is relatively amenable to biological degradation. We propose that the $T_{1}: T_{2}$ ratio can be quantified by measuring $\mathrm{SUVA}_{254}$ and demonstrated feasibility by presenting preliminary data for UK rivers. The measurement is simple and pragmatic, suitable for use across a range of contrasting and complex aquatic matrices. The calculation of $\mathrm{T}_{1}: \mathrm{T}_{2}$ involves a 2-component end-member approach based on UV absorbance (for details, see Supplementary Appendix 2). Nominally, $T_{1}$ represents terrigenous DOM that includes a large fraction of aromatic compounds, notably lignin, that are prone to photooxidation by UV (Cory et al. 2015; Koehler et al. 2016; Berggren et al. 2018). Photooxidation is not, however, restricted to these compounds and so the definitions of $\mathrm{T}_{1}$ and $\mathrm{T}_{2}$ based on UV absorbance do not necessarily map precisely with specific molecular structures. The relationship between $\mathrm{T}_{1}$ and $\mathrm{SUVA}_{254}$ cannot therefore be precise and universal.

The development of UniDOM highlights a perennial difficulty when it comes to understanding and quantifying DOM turnover, namely that DOM consists of a heterogeneous mix of substrates, and that the average composition tends to become relatively more recalcitrant with age as labile substrates are stripped out. This phenomenon takes on particular significance when attempting to quantify a progressively declining terrigenous DOC flux across the LOAC, including its 
circulation within the ocean. One solution is to divide DOM into pools of differing lability (Worrall and Moody 2014) such as the labile, semi-labile, refractory, terminology that is often used for ocean DOC (Kirchman et al. 1993; Carlson and Ducklow 1995; Hansell 2013). Any such division is, however, arbitrary and will have difficulty in capturing a long-lived pool that becomes progressively recalcitrant. Reactivity continuum modelling is an alternative approach where degradation rates are expressed as a continuous probability distribution of reactivity (Vähätalo et al. 2010; Koehler and Tranvik 2015; Vachon et al. 2017). It has not, however, been adopted in biogeochemical models because of the mathematical complexity involved. We developed a novel approach in UniDOM, where degradation rates of terrigenous DOC, both microbial and by photooxidation, are inversely proportional to DOM age as parameterised from empirical estimates of turnover versus water residence time for a wide variety of lakes (Catalán et al. 2016; Evans et al. 2017). Using $\alpha=0.38$ (the parameter that defines the rate of decline with DOC age), the turnover rate normalised to that of a freshly-produced substrate (age $=0$ ) is 1.0, 0.11, 0.044 and 0.018 day $^{-1}$ after 0, 1 , 10 and 100 years, respectively. Model predictions for DOC transfer across the LOAC showed high sensitivity to the value of $\alpha$, with $\alpha=0.38$ (our standard value) resulting in 5\% of the DOC released in catchments remaining after 2 years in the ocean, whereas $57 \%$ remains if $\alpha$ is doubled to 0.76 . If, on the other hand, the decline in lability with age is ignored $(\alpha=0)$, terrigenous DOC is rapidly depleted, with only a trace quantity $\left(\approx 10^{-6} \mathrm{mmol} \mathrm{C} \mathrm{m}^{-2}\right)$ remaining after 2 years in the ocean. The whole issue of how multiple processes, notably microbial turnover and photooxidation, interact to influence lability is complex. Photooxidation may make otherwise recalcitrant biomolecules available for use by microbes (e.g. Moran and Zepp 1997; Anesio et al. 2005; Cory et al. 2014), although the process may also consume some molecules that would otherwise have been available for biodegradation (Bowen et al. 2019; Bittar et al. 2015). The two processes may alternatively operate more or less independently on different components of the DOM pool (Benner and Kaiser 2011). Our work highlights the value of the empirical syntheses of DOC turnover versus water residence times by Catalán et al. (2016) and Evans et al. (2017) for understanding the fate of long-lived DOC, while emphasising the need for further work to understand the mechanistic underpinning of these relationships in terms of underlying processes and their parameterisation in models.

Model results were sensitive not only to the agerelated parameterisation, but also to base turnover rates for freshly produced DOC (age $=0$ ): we used $\eta_{1}$, $\eta_{2}=0.013,0.038$ day $^{-1}$ (biological turnover, $T_{1}, T_{2}$ ) and $\phi^{\text {ref }}=0.13$ day $^{-1}$ (photooxidation, fraction $\mathrm{T}_{1}$ ). It is unsurprising that a wide range of values for these rates is present in the literature, given variability between soil types, temperature, irradiance, etc., between sites. Photooxidation was predicted to account for $50 \%$ of turnover of the $\mathrm{T}_{1}$ fraction across the entire LOAC, including the coastal ocean. Our work thus emphasises the need to include this process in models of the coastal ocean. Further, a novel feature of UniDOM is that a fraction (20\%) of the autochthonous DOC pool was assumed to be coloured and subject to photooxidation, accounting for $13 \%$ of the resulting loss. Biological lability depends on multiple factors including low concentrations of individual biomolecules, presence of competing substrates and the structure and physiology of the bacterial community (Anderson et al. 2015a). The last of these could be of particular importance for DOC fluxes across the LOAC, although it is by no means easy to incorporate into UniDOM or other models. Priming is an example of the physiological flexibility of microbes, depending on circumstances (Bengtsson et al. 2018). The addition of simple sugars, such as those produced by algal exudation, can facilitate the breakdown of more refractory DOM (Bianchi et al. 2015; Ward et al. 2016).

A perhaps surprising outcome of our study is that flocculation was predicted to make only a minor contribution to the turnover of terrigenous DOC. Maximum rates were predicted for estuaries, but even there flocculation accounted for only $2.5 \%$ of DOC losses. The literature is equivocal on the quantitative significance of this process (e.g., Mantoura and Woodward 1983; Asmala et al. 2014) and our work serves to emphasise the need for further studies to resolve this uncertainty. We were unable to develop a mechanistic parameterisation of flocculation in UniDOM given that this process depends on a combination of chemical, physical and biological processes (Wang et al. 2013). Instead, simple quadratic functions were applied separately to freshwaters, estuaries and 
the ocean, where the values assigned to the rate parameters are only tentative.

The division of terrigenous DOC into fractions $\mathrm{T}_{1}$ and $\mathrm{T}_{2}$, and the associated parameterisations for turnover, were conceptualised on a universal basis. UniDOM is parameterised using literature data, substantially from the boreal northern hemisphere, and the model is investigated for a United Kingdom setting. Application of UniDOM at the global scale is desirable to develop a more complete understanding of DOM dynamics and land to ocean transfers. We currently lack suitable data sets to rigorously test UniDOM across the globe in a fully representative manner. A strength of the $\mathrm{T}_{1}: \mathrm{T}_{2}$ approach is that SUVA measurements correlate strongly with DOM aromaticity (Weishaar et al. 2003) and can therefore be used across both temperate and tropical environments (Graeber et al. 2015). Future work could extend SUVA measurements to a variety of contrasting systems in terms of soil type, residence time, etc., enabling model verification across a range of geographical settings. Relationships between model parameters and geographical characteristics could be sought in order to aid extrapolation to river systems that currently lack measurements. For example, microbial and photooxidation controls on DOM turnover could be related to temperature and irradiance.

The results presented herein provide a preliminary assessment, using a simple physical framework, of DOC transfer across the LOAC and the extent to which terrigenous DOC penetrates into the ocean. The predicted turnover of DOC was minimal in river systems, consistent with recent observations (Huntington et al. 2019). After 2 years of ocean transit, 5.0\% of terrigenous DOC was predicted to remain, following 1 and 3 day transit times for freshwater and estuary, respectively. This DOC flux decreased significantly, to $3.0 \%$, when an "average" UK lake, with residence time of 109 days, was included in the simulation, highlighting the importance of freshwaters in turnover of DOM and release of $\mathrm{CO}_{2}$ to the atmosphere. The residence time of DOM in freshwaters is hugely heterogeneous, ranging from a few days in short rivers draining high rainfall areas (such as some of those in UK) that lack significant lakes or impoundments, increasing in larger, dryer and/or impounded catchments, and rising to years, decades or even centuries in some lake-dominated areas (e.g.,
Evans et al. 2017 and references therein). This variation may give rise to order-of-magnitude variability in the predicted export of terrigenous DOM from land to the ocean, when combined with the uncertainty in the reactivity versus age relationships discussed above. Despite this uncertainty, the results presented indicate that the contribution of terrigenous DOC to the ocean pool may by no means be negligible. This finding is consistent with measureable concentrations of dissolved lignin in the open ocean (Hernes and Benner 2002; Medeiros et al. 2016) that indicate some terrigenous DOC traverses the LOAC without remineralisation, although this flux nevertheless remains poorly quantified and understood (Fichot et al. 2014; Medeiros et al. 2017).

In conclusion, UniDOM is the first model that is designed to explore the removal of terrigenous DOC across the entire LOAC, with preliminary results indicating that $\sim 5 \%$ of DOC produced in soils may penetrate the open ocean. Its unique structure incorporates separate state variables to represent terrigenous DOM, $\mathrm{T}_{1}$ (strongly-UV-absorbing) and $\mathrm{T}_{2}$ (nonor weakly-UV-absorbing), which show different susceptibilities to microbial consumption, photooxidation and flocculation. A novel parameterisation was derived for microbial turnover and photooxidation whereby rates of these processes were inversely related to DOC age. Model results were sensitive to this parameterisation, as well as values assigned to parameters for rates of these processes for freshlyproduced DOC. Predicted rates of flocculation were surprisingly low, although the sheer complexity of this process makes a mechanistic representation in models a nigh impossible task. Our work highlights the need for ongoing research into how different turnover processes impact DOC lability and how lability changes with age, all in context of the different environments of the LOAC. We anticipate that our findings will guide future attempts to refine understanding of DOC transport, remineralisation and transformation as it journeys from land to ocean.

Acknowledgements The work was funded by the Natural Environment Research Council, UK, as part of the Land Ocean Carbon Transfer (LOCATE; http://locate.ac.uk) project, grant number NE/N018087/1, including international workshops to develop the model formulation in Plymouth, May 2017 and Lancaster, February 2018. DAH was supported by U.S. NSF OCE-1436748, AJW by the NERC NE/J011967/1 and HW by MWK-BIME (ZN 3184). BGS authors publish with the 
permission of the Executive Director, BGS NERC-UKRI. We wish to thank two anonymous reviewers for their helpful and constructive comments.

Open Access This article is distributed under the terms of the Creative Commons Attribution 4.0 International License (http:// creativecommons.org/licenses/by/4.0/), which permits unrestricted use, distribution, and reproduction in any medium, provided you give appropriate credit to the original author(s) and the source, provide a link to the Creative Commons license, and indicate if changes were made.

\section{References}

Anderson TR, Ducklow HW (2001) Microbial loop carbon cycling in ocean environments studied using a simple steady-state model. Aquat Microb Ecol 26:37-49

Anderson TR, Williams PJ le B (1998) Modelling the seasonal cycle of dissolved organic carbon at Station $E_{1}$ in the English Channel. Est Coast Shelf Sci 46:93-109

Anderson TR, Williams PJ le B (1999) A one-dimensional model of dissolved organic carbon cycling in the water column incorporating combined biological-photochemical decomposition. Glob Biogeochem Cycles 13:337-349

Anderson TR, Christian JR, Flynn KJ (2015a) Modeling DOM biogeochemistry. In: Hansell DA, Carlson CA (eds) Biogeochemistry of marine dissolved organic matter. Academic Press, Burlington, pp 635-667

Anderson TR, Gentleman WC, Yool A (2015b) EMPOWER1.0: an efficient model of planktonic ecosystems written in R. Geosci Mod Dev 8:2231-2262

Anesio AM, Granéli W, Aiken GR, Kieber DJ, Mopper K (2005) Effect of humic substance photodegradation on bacterial growth and respiration in lake water. Appl Environ Microbiol 71:6267-6275

Asmala E, Bowers DG, Autio R, Kaartokallio H, Thomas DN (2014) Qualitative changes of riverine dissolved organic matter at low salinities due to flocculation. J Geophys Res Biogeosci 119:1919-1933

Bauer JE, Cai W-J, Raymond PA, Bianchi TS, Hopkinson CS, Regnier PA (2013) The changing carbon cycle of the coastal ocean. Nature 504:61-70

Bengtsson MM, Attermeyer K, Catalán N (2018) Interactive effects on organic matter processing from soils to the ocean: are priming effects relevant in aquatic ecosystems? Hydrobiologia 822:1-17

Benner R, Kaiser K (2011) Biological and photochemical transformations of amino acids and lignin phenols in riverine dissolved organic matter. Biogeochemistry 102:209-222

Berggren M, del Giorgio PA (2015) Distinct patterns of microbial metabolism associated to riverine dissolved organic carbon of different source and quality. J Geophys Res Biogeosci 120:989-999

Berggren M, Klaus M, Selvam BP, Ström L, Laudon H, Jansson M, Karlsson J (2018) Quality transformation of dissolved organic carbon during water transit through lakes: contrasting controls by photochemical and biological processes. Biogeosciences 15:457-470

Bertilsson S, Tranvik LJ (1998) Photochemically produced carboxylic acids as substrates for freshwater bacterioplankton. Limnol Oceanogr 43:885-895

Bianchi TS, Thornton DCO, Yvon-Lewis SA, King GM, Eglinton TI, Shields MR, Ward ND, Curtis J (2015) Positive priming of terrestrially derived dissolved organic matter in a freshwater microcosm system. Geophys Res Lett 42:5460-5467

Bittar TB, Vieira AAH, Stubbins A, Mopper K (2015) Competition between photochemical and biological degradation of dissolved organic matter from the cyanobacteria Microcystis aeruginosa. Limnol Oceanogr 60:1172-1194

Blaas M, Kerkhoven D, de Swart HE (2001) Large-scale circulation and flushing characteristics of the North Sea under various climate forcings. Clim Res 18:47-54

Bowen JC, Kaplan LA, Cory RM (2019) Photodegradation disproportionately impacts biodegradation of semi-labile DOM in streams. Limnol Oceanogr. https://doi.org/10. 1002/lno. 11244

Bradley RI, Milne R, Bell J, Lilly A, Jordan C, Higgins A (2005) A soil carbon and land use database for the United Kingdom. Soil Use Manage 21:363-369

Butman DE, Wilson HF, Barnes RT, Xenopoulos MA, Raymond PA (2014) Increased mobilization of aged carbon to rivers by human disturbance. Nat Geosci 8:112-116

Capuzzo E, Lynam CP, Barry J, Stephens D, Forster RM, Greenwood N, McQuatters-Gollop A, Silva T, van Leeuwen SM, Engelhard GH (2018) A decline in primary production in the North Sea over 25 years, associated with reductions in zooplankton abundance and fish stock recruitment. Glob Chang Biol 24:e352-e364

Carlson CA, Ducklow HW (1995) Dissolved organic carbon in the upper ocean of the central equatorial Pacific Ocean, 1992: daily and finescale vertical variations. Deep Sea Res II 42:639-656

Carter HT, Tipping E, Koprivnjak J-F, Miller MP, Cookson B, Hamilton-Taylor J (2012) Freshwater DOM quantity and quality from a two-component model of UV absorbance. Water Res 46:4532-4542

Catalán N, Marcé R, Kothawala DN, Tranvik LJ (2016) Organic carbon decomposition rates controlled by water retention time across inland waters. Nat Geosci 9:501-506

Charette MA, Sholkovitz ER (2002) Oxidative precipitation of groundwater-derived ferrous iron in the subterranean estuary of a coastal bay. Geophys Res Lett 29:1444. https:// doi.org/10.1029/2001GL014512

Chróst RJ (1990) Microbial ectoenzymes in aquatic environments. In: Chrost RJ, Overbeck J (eds) Aquatic microbial ecology: biochemical and molecular approaches. Springer, New York, pp 47-78

Ciais P, Sabine C, Bala G, Bopp L, Brovkin V, Canadell J, Chhabra A, DeFries R, Galloway J, Heimann M, Jones C, Le Quéré C, Myneni RB, Piao S, Thornton P (2013) Carbon and other biogeochemical cycles. In: Climate Change 2013: The Physical science basis. Contribution of Working Group I to the Fifth Assessment Report of the Intergovernmental Panel on Climate Change (Stocker TF, Qin D, Plattner G-K, Tignor M, Allen SK, Boschung J, Nauels A, 
Xia Y, Bex V, Midgley PM eds). Cambridge University Press, Cambridge

Coble PG (2007) Marine optical biogeochemistry: the chemistry of ocean color. Chem Rev 107:402-418

Cole JJ, Prairie YT, Caraco NF, McDowell WH, Tranvik LJ, Striegel RG, Duarte CM, Kortelainen P, Downing JA, Middelburg JJ, Melack J (2007) Plumbing the global carbon cycle: integrating inland waters into the terrestrial carbon budget. Ecosystems 10:172-185

Cory RM, Ward CP, Crump BC, Kling GW (2014) Sunlight controls water column processing of carbon in arctic fresh waters. Science 345:925-928

Cory RM, Harrold KH, Neilson BT, Kling GW (2015) Controls on dissolved organic matter (DOM) degradation in a headwater stream: the influence of photochemical and hydrological conditions in determining light-limitation or substrate-limitation of photo-degradation. Biogeosciences 12:6669-6685

Drake TW, Raymond PA, Spencer RGM (2018) Terrestrial carbon inputs to inland waters: a current synthesis of estimates and uncertainty. Limnol Oceanogr Lett 3:132-142

Evans CD, Page SE, Jones T, Moore S, Gauci V, Laiho R, Hruška J, Allott TEH, Billett MF, Tipping E, Freeman C, Garnett MH (2014) Contrasting vulnerability of drained tropical and high-latitude peatlands to fluvial loss of stored carbon. Glob Biogeochem Cycles 28:1215-1234

Evans CD, Futter MN, Moldan F, Valinia S, Frogbrook Z, Kothawala DN (2017) Variability in organic carbon reactivity across lake residence time and trophic gradients. Nat Geosci 10:832-837

Fichot CG, Lohrenz SE, Benner R (2014) Pulsed, cross-shelf export of terrigenous dissolved organic carbon to the Gulf of Mexico. J Geophys Res Oceans 119:1176-1194

Futter MN, Butterfield D, Cosby BJ, Dillon PJ, Wade AJ, Whitehead PG (2007) Modeling the mechanisms that control in-stream dissolved organic carbon dynamics in upland and forested catchments. Water Resour Res 43:W02424. https://doi.org/10.1029/2006WR004960

Geeraert N, Omengo FO, Govers G, Bouillon S (2016) Dissolved organic carbon lability and stable isotope shifts during microbial decomposition in a tropical river system. Biogeosciences 13:517-525

Geyer WR, Scully ME, Ralston DK (2008) Quantifying vertical mixing in estuaries. Environ Fluid Mech 8:495-509

Gonsior M, Schmitt-Kopplin P, Bastviken D (2013) Depth dependent molecular composition and photo-reactivity of dissolved organic matter in a boreal lake under winter and summer conditions. Biogeosciences 10:6945-6956

Gonsior M, Hertkorn N, Conte MH, Cooper WJ, Bastviken D, Druffel E, Schmitt-Kopplin P (2014) Photochemical production of polyols arising from significant photo-transformation of dissolved organic matter in the oligotrophic surface ocean. Mar Chem 163:10-18

Graeber D, Goyenola G, Meerhoff M, Zwirnmann E, Ovesen NB, Glendell M, Gelbrecht J, Teixeira de Mello F, González-Bergonzoni I, Jeppesen E, Kronvang B (2015) Interacting effects of climate and agriculture on fluvial DOM in temperate and subtropical catchments. Hydrol Earth Syst 19:2377-2394
Graneli W, Lindell M, Tranvik L (1996) Photo-oxidative production of dissolved inorganic carbon in lakes of different humic content. Limnol Oceanogr 41:698-706

Gunnison D, Alexander M (1975) Basis for the resistance of several algae to microbial decomposition. Appl Microbiol 29:729-738

Hansell DA (2013) Recalcitrant dissolved organic carbon fractions. Annu Rev Mar Sci 5:421-445

Hansell DA, Carlson CA (1998) Deep ocean gradients in dissolved organic carbon concentrations. Nature 395:263-266

Hedges JI, Keil RG, Benner R (1997) What happens to terrestrial organic matter in the ocean? Org Geochem 27:195-212

Helms JR, Stubbins A, Perdue EM, Green NW, Chen H, Mopper K (2013) Photochemical bleaching of oceanic dissolved organic matter and its effect on absorption spectral slope and fluorescence. Mar Chem 155:81-91

Helms JR, Mao J, Stubbins A, Schmidt-Rohr K, Spencer RGM, Hernes PJ, Mopper K (2014) Loss of optical and molecular indicators of terrigenous dissolved organic matter during long-term photobleaching. Aquat Sci 76:353-373

Her N, Amy G, McKnight D, Sohn J, Yoon Y (2003) Characterization of DOM as a function of MW by fluorescence EEM and HPLC-SEC using UVA, DOC, and fluorescence detection. Water Res 37:4295-4303

Hernes PJ, Benner R (2002) Transport and diagenesis of dissolved and particulate terrigenous organic matter in the North Pacific Ocean. Deep Sea Res Part I 49:2119-2132

Hopkinson CS, Buffam I, Hobbie J, Vallino J, Perdue M, Eversmeyer B, Prahl F, Covert J, Hodson R, Moran MA, Smith E, Baross J, Crump B, Findlay S, Foreman K (1998) Terrestrial inputs of organic matter to coastal ecosystems: an intercomparison of chemical characteristics and bioavailability. Biogeochemistry 43:211-234

Huntington TG, Roesler CS, Aiken GR (2019) Evidence for conservative transport of dissolved organic carbon in major river basins in the Gulf of Maine Watershed. J Hydrol 573:755-767

Janssen EML, McNeill K (2014) Environmental photoinactivation of extracellular phosphatases and the effects of dissolved organic matter. Environ Sci Technol 49:889-896

Kaiser K, Kalbitz K (2012) Cycling downwards-dissolved organic matter in soils. Soil Biol Biochem 52:29-32

Kalbitz K, Schmerwitz J, Schwesig D, Matzner E (2003) Biodegradation of soil-derived dissolved organic matter as related to its properties. Geoderma 113:273-291

Kellerman AM, Guillemette F, Podgorski DC, Aiken GR, Butler KD, Spencer RGM (2018) Unifying concepts linking dissolved organic matter composition to persistence in aquatic ecosystems. Environ Sci Technol 52:538-2548

Kepkay PE (1994) Particle aggregation and the biological reactivity of colloids. Mar Ecol Prog Ser 109:293-304

Kinsey JD, Corradino G, Ziervogel K, Schnetzer A, Osburn CL (2018) Formation of chromophoric dissolved organic matter by bacterial degradation of phytoplankton-derived aggregates. Front Mar Sci 4:430. https://doi.org/10.3389/ fmars.2017.00430

Kirchman DL, Lancelot C, Fasham MJR, Legendre L, Radach G, Scott M (1993) Dissolved organic matter in biogeochemical models of the ocean. In: Evans GT, Fasham MJR 
(eds) Towards a model of ocean biogeochemical processes. Springer, Berlin, pp 209-225

Kirk TK, Farrell RL (1987) Enzymatic combustion: the microbial degradation of lignin. Annu Rev Microbiol 41:465-505

Koehler B, Tranvik LJ (2015) Reactivity continuum modeling of leaf, root, and wood decomposition across biomes. J Geophys Res Biogeosci 120:1196-1214

Koehler B, Broman E, Tranvik LJ (2016) Apparent quantum yield of photochemical dissolved organic carbon mineralization in lakes. Limnol Oceanogr 61:2207-2221

Köhler SJ, Kothawala D, Futter MN, Liungman O, Tranvik L (2013) In-lake processes offset increased terrestrial inputs of dissolved organic carbon and color to lakes. PLoS ONE 8:e70598

Kutser T, Pierson DC, Kallio KY, Reinart A, Sobek S (2005) Mapping lake CDOM by satellite remote sensing. Remote Sens Environ 94:535-540

Le Quéré C, Moriarty R, Andrew RM et al (2015) Global carbon budget 2014. Earth Syst Sci Data 7:47-85

Mann KH (1988) Production and use of detritus in various freshwater, estuarine, and coastal marine systems. Limnol Oceanogr 33:910-930

Mantoura RFC, Woodward EMS (1983) Conservative behaviour of riverine dissolved organic carbon in the Severn Estuary: chemical and geochemical implications. Geochim Cosmochim Acta 47:1293-1309

Massicotte P, Asmala E, Stedmon C, Markager S (2017) Global distribution of dissolved organic matter along the aquatic continuum: across rivers, lakes and oceans. Sci Tot Environm 609:180-191

McKnight DM, Boyer EW, Westerhoff PK, Doran PT, Kulbe T, Andersen DT (2001) Spectrofluorometric characterization of dissolved organic matter for indication of precursor organic material and aromaticity. Limnol Oceanogr 46:38-48

Medeiros PM, Seidel M, Powers LC, Dittmar T, Hansell DA, Miller WL (2015) Dissolved organic matter composition and photochemical transformations in the northern North Pacific Ocean. Geophys Res Lett 42:863-870

Medeiros P, Seidel M, Niggemann J, Spencer R, Hernes P, Yager P, Miller W, Dittmar T, Hansell DA (2016) A novel molecular approach for tracing terrigenous dissolved organic matter into the deep ocean. Glob Biogeochem Cycles 30:689-699

Medeiros PM, Babcock-Adams L, Seidel M, Castelao RM, Di Iorio D, Hollibaugh JT, Dittmar T (2017) Export of terrigenous dissolved organic matter in a broad continental shelf. Limnol Oceanogr 62:1718-1731

Meyers-Schulte KJ, Hedges JI (1986) Molecular evidence for a terrestrial component of organic matter dissolved in ocean water. Nature 321:61-63

Moran MA, Zepp RG (1997) Role of photoreactions in the formation of biologically labile compounds from dissolved organic matter. Limnol Oceanogr 42:1307-1316

Mostovaya A, Koehler B, Guillemette F, Brunberg A-K, Tranvik LJ (2016) Effects of compositional changes on reactivity continuum and decomposition kinetics of lake dissolved organic matter. J Geophys Res Biogeosci 121:1733-1746
Neff JC, Finlay JC, Zimov SA, Davydov SP, Carrasco JJ, Schur EAG, Davydova AI (2006) Seasonal changes in the age and structure of dissolved organic carbon in Siberian rivers and streams. Geophys Res Lett 33:L23401

Nelson NB, Siegel DA (2013) The global distribution and dynamics of chromophoric dissolved organic matter. Annu Rev Mar Sci 5:447-476

Nelson NB, Carlson CA, Steinberg DK (2004) Production of chromophoric dissolved organic matter by Sargasso Sea microbes. Mar Chem 89:273-287

Opsahl S, Benner R (1997) Distribution and cycling of terrigenous dissolved organic matter in the ocean. Nature 386:480-482

Opsahl S, Benner R (1998) Photochemical reactivity of dissolved lignin in river and ocean waters. Limnol Oceanogr 43:1297-1304

Painter SC, Lapworth DJ, Woodward EMS, Kroeger S, Evans CD, Mayor DJ, Sanders RJ (2018) Terrestrial dissolved organic matter distribution in the North Sea. Sci Total Environ 630:630-647

Pereira R, Bovolo CI, Spencer RG, Hernes PJ, Tipping E, ViethHillebrand A, Pedentchouk N, Chappell NA, Parkin G, Wagner T (2014) Mobilization of optically invisible dissolved organic matter in response to rainstorm events in a tropical forest headwater river. Geophys Res Lett 41:1202-1208

Prandle D (1984) A modelling study of the mixing of ${ }^{137} \mathrm{Cs}$ in the seas of the European Continental Shelf. Philos Trans R Soc Lond A 310:407-436

Prandle D, Lane A (2015) Sensitivity of estuaries to sea level rise: vulnerability indices. Est Coast Shelf Sci 160:60-68

Raymond PA, Saiers JE (2010) Event controlled DOC export from forested watersheds. Biogeochemistry 100:197-209

Raymond PA, Spencer RGM (2015) Riverine DOM. In: Hansell DA, Carlson CA (eds) Biogeochemistry of marine dissolved organic matter, 2nd edn. Elsevier, Amsterdam, pp 509-533

Riedel T, Biester H, Dittmar T (2012) Molecular fractionation of dissolved organic matter with metal salts. Environ Sci Technol 46:4419-4426

Riedel T, Zark M, Vähätalo AV, Niggemann J, Spencer RGM, Hernes PJ, Dittmar T (2016) Molecular signatures of biogeochemical transformations in dissolved organic matter from ten world rivers. Front Earth Sci. 4:85. https://doi.org/ 10.3389/feart.2016.00085

Rochelle-Newall EJ, Fisher TR (2002) Production of chromophoric dissolved organic matter fluorescence in marine and estuarine environments: an investigation into the role of phytoplankton. Mar Chem 77:7-21

Romera-Castillo C, Sarmento H, Alvarez-Salgado XA, Gasol JM, Marrase C (2011) Net production and consumption of fluorescent colored dissolved organic matter by natural bacterial assemblages growing on marine phytoplankton exudates. Appl Environ Microbiol 77:7490-7498

Rowe EC, Tipping E, Posch M, Oulehle F, Cooper DM, Jones TG, Burden A, Hall J, Evans CD (2014) Predicting nitrogen and acidity effects on long-term dynamics of dissolved organic matter. Environ Poll 184:271-282

Salihoglu B, Garçon V, Oschlies A, Lomas MW (2008) Influence of nutrient utilization and remineralization 
stoichiometry on phytoplankton species and carbon export: a modeling study at BATS. Deep Sea Res I 55:73-107

Santschi PH (2018) Marine colloids, agents of the self-cleansing capacity of aquatic systems: historical perspective and new discoveries. Mar Chem 207:124-135

Schmittner A, Oschlies A, Giraud X, Eby M, Simmons HL (2005) A global model of the marine ecosystem for longterm simulations: sensitivity to ocean mixing, buoyancy forcing, particle sinking, and dissolved organic matter cycling. Global Biogeochem Cycles 19:GB3004. https:// doi.org/10.1029/2004gb002283

Shiller AM, Duan S, van Erp P, Bianchi TS (2006) Photo-oxidation of dissolved organic matter in river water and its effect on trace element speciation. Limnol Oceanogr 51:1716-1728

Søndergaard M, Middelboe M (1995) A cross-system analysis of labile dissolved organic carbon. Mar Ecol Prog Ser 118:283-294

Spencer RGM, Stubbins A, Hemes PJ, Baker A, Mopper K, Aufdenkampe AK, Dyda RY, Mwamba VL, Mangangu AM, Wabakanghanzi JN, Six J (2009) Photochemical degradation of dissolved organic matter and dissolved lignin phenols from the Congo River. J Geophys Res 114:G03010. https://doi.org/10.1029/2009JG000968

Steele JH (1974) The Structure of Marine Ecosystems. Harvard Univ. Press, Cambridge, p 128

Tedetti M, Sempéré R (2006) Penetration of ultraviolet radiation in the marine environment. A review. Photochem Photobiol 82:389-397

Thacker SA, Tipping E, Gondar D, Baker A (2008) Functional properties of DOM in a stream draining blanket peat. Sci Tot Environ 407:566-573

Tipping E, Corbishley HT, Koprivnjak J-F, Lapworth DJ, Miller MP, Vincent CD, Hamilton-Taylor J (2009) Quantification of natural DOM from UV absorption at two wavelengths. Environ Chem 6:472-476

Tipping E, Chamberlain PM, Fröberg M, Hanson PJ, Jardine PM (2012) Simulation of carbon cycling, including dissolved organic carbon transport, in forest soil locally enriched with ${ }^{14} \mathrm{C}$. Biogeochemistry 108:91-107

Tipping E, Boyle JF, Schillereff DN, Spears BM, Phillips G (2016) Macronutrient processing by temperate lakes: a dynamic model for long-term, large-scale application. Sci Total Environm 572:1573-1585

Tranvik LJ, Downing JA, Cotner JB, Loiselle SA, Striegl RG, Ballatore TJ, Dillon P, Finlay K, Fortino K, Knoll LB, Kortelainen PL, Kutser T, Larsen S, Laurion I, Leech DM, McCallister SL, McKnight DM, Melack JM, Overholt E, Porter JA, Prairie Y, Renwick WH, Roland F, Sherman BS, Schindler DW, Sobek S, Tremblay A, Vanni MJ, Verschoor AM, von Wachenfeldt E, Weyhenmeyer GA (2009) Lakes and reservoirs as regulators of carbon cycling and climate. Limnol Oceanogr 54:2298-2314

Uncles RJ, Stephens JA, Smith RE (2002) The dependence of estuarine turbidity on tidal intrusion length, tidal range and residence time. Cont Shelf Res 22:1835-1856

Vachon D, Prairie YT, Guillemette F, del Giorgio PA (2017) Modeling allochthonous dissolved organic carbon mineralization under variable hydrologic regimes in boreal lakes. Ecosystems 20:781-795
Vähätalo AV, Aarnos H, Mäntyniemi S (2010) Biodegradability continuum and biodegradation kinetics of natural organic matter described by the beta distribution. Biogeochemistry 100:227-240

Verhoeven JTA, Liefveld WM (1997) The ecological significance of organochemical compounds in Sphagnum. Acta Bot Neerl 46:117-130

Vilge-Ritter A, Masion A, Boulange T, Rybacki D, Bottero JY (1999) Removal of natural organic matter by coagulationflocculation: a pyrolysis-GC-MS study. Environ Sci Technol 33:3027-3032

Vinh VD, Ouillon S, Uu DV (2018) Estuarine turbidity maxima and variations of aggregate parameters in the Cam-Nam Trieu Estuary, North Vietnam, in early wet season. Water 10:68. https://doi.org/10.3390/w10010068

Wang YP, Voulgaris G, Li Y, Yang Y, Gao J, Chen J, Gao S (2013) Sediment resuspension, flocculation, and settling in a macrotidal estuary. J Geophys Res Oceans 118:5591-5608

Ward ND, Richey JE, Keil RG (2012) Temporal variation in river nutrient and dissolved lignin phenol concentrations and the impact of storm events on nutrient loading to Hood Canal, Washington, USA. Biogeochemistry 111:629-645

Ward ND, Bianchi TS, Sawakuchi HO, Gagne-Maynard W, Cunha AC, Brito DC, Neu V, Matos Valerio A, Silva R, Krusche AV, Richey JE (2016) The reactivity of plantderived organic matter and the potential importance of priming effects along the lower Amazon River. J Geophys Res Biogeosci 121:1522-1539

Ward ND, Bianchi TS, Medeiros PM, Seidel M, Richey JE, Keil RG, Sawakuchi HO (2017) Where carbon goes when water flows: carbon cycling across the aquatic continuum. Front Mar Sci 4:7. https://doi.org/10.3389/fmars.2017.00007

Webster JR, Benfield EF (1986) Vascular plant breakdown in freshwater ecosystems. Ann Rev Ecol Syst 17:567-594

Weishaar JL, Aiken GR, Bergamasch BA, Fram MS, Fujii R, Mopper K (2003) Evaluation of specific ultraviolet absorbance as an indicator of the chemical composition and reactivity of dissolved organic carbon. Environ Sci Technol 37:4702-4708

Wiegner TN, Seitzinger SP (2004) Seasonal bioavailability of dissolved organic carbon and nitrogen from pristine and polluted freshwater wetlands. Limnol Oceanogr 49:1703-1712

Worrall F, Moody CS (2014) Modeling the rate of turnover of DOC and particulate organic carbon in a UK, peat-hosted stream: including diurnal cycling in short-residence time systems. J Geophys Res Biogeosci 119:1934-1946

Worrall F, Howden NJK, Burt TP (2014) A method of estimating in-stream residence time of water in rivers. J Hydrol 512:274-284

Xie H, Zafiriou OC, Cai W-J, Zepp RG, Wang Y (2004) Photooxidation and its effects on the carboxyl content of dissolved organic matter in two coastal rivers in the southeastern United States. Environ Sci Technol 38:4113-4119

Yuan D, Lin B, Falconer RA (2007) A modelling study of residence time in a macro-tidal estuary. Est Coast Shelf Sci 71:401-411

Publisher's Note Springer Nature remains neutral with regard to jurisdictional claims in published maps and institutional affiliations. 